\title{
The fishing footprint of a tourism-based economy: displacing seafood consumption from local to distant waters in the Balearic Islands
}

\author{
Ivan Murray Mas ${ }^{1}$ \\ University of the Balearic Islands, Spain
}

\begin{abstract}
Since the Balearics are one of the key tourism destinations in Europe, the tourism industry has entailed a radical transformation of coastal life on the islands. In the 1960s and 1970s, fish captures increased enormously due to the expansion of consumption derived from tourism, and through technological improvements. There has been a change in target species from cheap fish consumed by local people towards expensive species consumed by tourists. However, since the 1980s a combination of factors including the adoption of the EU Common Fisheries Policy, the globalization of trade, and overfishing of some target species has led to a drastic fall in fishing sector jobs, catch reductions, and an increase in cheap imports. This article analyses the transformation of Balearic fisheries combining ecological economics (EE) and political ecology (PE) approaches. Material flow accounting (MFA) and the ecological footprint (EF) are applied in order to conceptualize the biophysical dimension of fisheries in relation to the historical dynamics of capital in the archipelago. Between 1940 and 2012, total fish catches doubled the official landings, while nonreported or hidden catches were underestimated. In the neoliberal period (1990-2012), fish catches decreased and seafood consumption was satisfied mainly through imports, five times the local captures. Thus, the metabolism of fish consumption in the Balearics illustrates the logics of capital and its metabolism in advanced capitalist regions, characterized by the displacement of socio-ecological conflicts to distant waters.
\end{abstract}

Keywords: Balearic Islands; tourism; fisheries; material flow accounting; ecological footprint.

\section{Résumé}

Depuis les Baléares sont l'une des principales destinations touristiques en Europe, l'industrie du tourisme a entraîné une transformation radicale de la vie sur les îles côtières. Dans les années 1960 et 1970, les captures de poissons a énormément augmenté en raison de l'expansion de la consommation d'un secteur touristique en plein essor, et les améliorations technologiques. Il y a eu un changement dans les espèces cibles de poissons pas cher consommée par les populations locales à l'égard des espèces coûteuses consommés par les touristes. Cependant, depuis les années 1980, il y a eu une chute drastique dans les emplois du secteur de la pêche, une réduction des captures, et une augmentation des importations à bas prix. Ceci a été causé par l'adoption de la politique commune de la pêche de l'UE, la mondialisation des échanges, et la surpêche de certaines espèces cibles. Cet article analyse la transformation de la pêche Baléares en combinant une approche de l'économie écologique (EE) et de l'écologie politique (PE). La comptabilité des flux de matières (AMF) et l'empreinte écologique sont appliqués afin de conceptualiser la dimension biophysique de la pêche dans le cadre de la dynamique historique du capital de l'archipel. Entre 1940 et 2012, les captures officielles de poisson a doublé, tandis que les captures non déclarées ou cachées ont été sous-estimés. Dans la période néolibérale (19902012), les prises de poissons ont diminué et la consommation de fruits de mer, satisfaite surtout par les importations, cinq fois les captures locales. Ainsi, le métabolisme de la consommation de poisson dans les Baléares illustre les logiques de capital et de son métabolisme dans les régions capitalistes avancés, caractérisé par le déplacement des conflits socio-écologiques à des eaux lointaines.

Mots-clés: Îles Baléares, tourisme, pêche, comptables des flux de matières, empreinte écologique.

\footnotetext{
${ }^{1}$ Dr. Ivan Murray Mas, Associate Professor, Earth Sciences Department, the University of the Balearic Islands (Universitat de les Illes Balears), Palma, Spain. Email: ivan.murray "at" uib.es. This research was funded by the Spanish Ministry for Science and Innovation, project CSO2012-30840, and the Social Sciences and Humanities Research Council of Canada, project SSHRC 895-2011-1020. I express my gratitude to Jaume Adrover, Macià Blázquez, Óscar Carpintero, Joan Moranta, Raquel Vaquer, and Christos Zografos, the Journal for editing, and two anonymous referees.
} 


\section{Resumen}

Teniendo en cuenta que las Baleares son uno de los principales enclaves del turismo europeo, el turismo ha sido la pieza central de las potentes transformaciones de la vida costera del archipiélago. En los años 1960 y 1970, las capturas pesqueras aumentaron notablemente empujadas por la especialización turística y los cambios tecnológicos del sector pesquero. Además del aumento de las capturas se produjo un cambio en las especies desembarcadas, pasando de aquellas consumidas por las clases populares a las consumidas por turistas. Sin embargo, a partir de la década de los 1980, la combinación de factores como la adopción de la Política Pesquera Común de la UE y la globalización comercial, junto con las claras muestras de sobreexplotación de algunas pesquerías, desembocó en un cambio drástico caracterizado por la constante disminución de puestos de trabajo en la pesca, la reducción de las capturas y el aumento de las importaciones de bajo precio. Este artículo analiza la pesca combinando los enfoques de la economía ecológica (EE) y la ecología política (EP). Se aplica la contabilidad de los flujos de materiales flujo (CFM) y la huella ecológica (HE) con el fin de conceptualizar la dimensión biofísica de la pesca para relacionarla con la dinámica histórica del capital en el archipiélago. Entre 1940 y 2012, las capturas totales han representado el doble de los desembarques oficiales, destacando el hecho que las fracciones no reportadas u ocultas permiten a profundizar en aspectos políticos que a menudo son subestimados. Por otro lado, durante el período neoliberal (1990-2012), las capturas pesqueras han disminuido y el consumo se ha satisfecho principalmente a través de las importaciones, quintuplicando la pesca local. De este modo, el metabolismo del consumo de pescado en las Baleares es un claro ejemplo de las lógicas del capital y su metabolismo en los espacios del capitalismo avanzado, caracterizados por el desplazamiento de los conflictos socio-ecológicos hacia mares distantes.

Palabras Clave: Islas Baleares, turismo, pesca, contabilidad del flujo de materiales, huella ecológica.

\section{Introduction}

Marine ecosystems and fisheries are seriously threatened by overfishing, but also by land based activities and global environmental variability. Since the mid 20th century, global fishing efforts have increased dramatically and powerful fleets owned by large corporations have expanded to more distant waters. Fisheries have been harvested to a point that their reproduction is threatened, and marine food webs greatly altered (Halpern et al. 2008; Pauly et al. 2002). The fisheries crisis is an expression of the contradictions of capital according to Clausen and Clark (2005), who extend the notion of the metabolic rift, developed by Marx. According to Mansfield (2010, 2011) mainstream explanations of overfishing state the problem in terms of "the tragedy of the commons", ignoring the political dimension of fisheries. Orthodox approaches reinforce the neoliberal approach to fisheries with the expansion of property rights (i.e. transferable quotas) and financial logics (Pedersen et al. 2014), as well as new fixes such as aquaculture (Mansfield 2010) and recreational fishing (Ditton et al. 2002).

At present, the Mediterranean Sea, hosting approximately $10 \%$ of world's marine biodiversity, is under siege due to cumulative and interacting impacts derived from coastal, fishing and inland activities (Coll et al. 2011). Moreover, the Mediterranean has been identified as one of the areas where human impacts on marine ecosystems are predicted to increase (Goffredo and Duinsky 2013). The Mediterranean also concentrates the global contradictions of capital with extreme patterns of uneven geographical development along its borders (Dunford 2014).

Coastal and insular regions worldwide have embraced tourism as a major accumulation strategy. Previous studies have identified: first, the displacement of fishing by tourism with little benefit for artisanal fishers and local communities (Hoefle 2014); second, the promotion of tourism in order to substitute for commercial overfishing, with ambiguous results (Fabinyi 2010; Lovelock et al. 2010); and third, using ecotourism as a strategy to preserve marine ecosystems and as a form of 'blue grabbing' (Benjaminsen and Bryceson 2012). Given this breadth of approaches, studies are needed in situations where tourism has altered fishing patterns.

In the Spanish Balearic Islands, tourism has become the driving force of the archipelago's capitalist sector since the mid 20th century. The Balearics were the first major tourist region in Spain, in terms of foreign visitors and hotel beds. The island state is collectively the third largest tourist destination worldwide (Murray 2015). The tourist drive has been accompanied by the evolution of the fishing industry. Also, with 
the deepening of neoliberal policies and the tourism monoculture, the footprint of seafood consumption of the Balearic Islands has been extended to distant waters, as a clear example of unequal ecological exchange (Hornborg 2012).

The article covers a period of Spanish history from the long Franco dictatorship (1936-1975) and democracy (1976 to present). Different phases correspond to the main regimes of accumulation on a global scale, but with some particularities. Accordingly, three main periods are: autarky (1936-1959) with the Spanish Civil War (1936-1939) and the international blockade against the fascist regime (1939-1959); second, the adoption of the adjustment programs dictated by multilateral institutions and a Fordist regime (1959-1986) and desarrollismo (1959-1975); then crisis and transition (1975-1982) and entrance into the neoliberal block of the European Union (1986); and finally, neoliberalism from 1986 to the present (Etxezarreta 1991; López and Rodríguez 2010; Rodríguez 2015).

Capital accumulation through tourism has inserted the islands into global circuits, reshaping socioecological relationships (Murray 2012). The main research questions posed are:

1) How have fish landings and total catches evolved in relation to an evolving tourism specialization?

2) What are the total fish catches and the footprint of fishing?

3) How important are fish imports to the satisfaction of seafood consumption?

4) How has the footprint of seafood consumption changed through years of economic growth and crisis?

In responding to these questions, I combine different epistemological approaches: biophysical accounting derived from ecological economics (EE) with socio-political analysis derived from political ecology (PE).

The article is organized as follows. Section two details work on social metabolism and accounting techniques, followed by the methods used to account for the ecological footprint of fishing and the materials used. Next, there is a brief introduction to the Balearic islands. Then, sections five to seven are the case study results, analyzed using an eclectic approach where fisheries' accounting is merged with PE. It should be noted that while the ecological footprint of fisheries of the Balearics is analyzed for the whole period (1940-2012), but the ecological footprint of seafood consumption was only for the neoliberal period (1990-2012) due to data limitations on fish trade prior to 1990. Section eight discusses the exploitation of marine resources beyond fishing, termed Blue Capitalism. This is being promoted by the EU as one solution to a financial crisis. Finally, conclusions are drawn in order to think beyond the neoliberal agenda for fishing and Blue Capitalism.

\section{Social metabolism}

The metaphor of 'social metabolism' originates from different scholarly approaches: from industrial ecology (IE) or ecological economics (EE), and political ecology (PE) and systems ecology theory (Newell and Cousins 2014). Within IE and EE, the metabolic metaphor refers to socio-ecological dialectics, in terms of the energy and material flows required to maintain the internal structure of social systems (Fisher-Kowalski and Haberl 2007). Material Flow Accounting (MFA) is one of the main methodologies used to conceptualize social metabolism. It accounts for the materials, biotic and abiotic, which pass through social systems (Eurostat 2012; Fischer-Kowalski et al. 2011). The Ecological Footprint (EF) proposed by Wackernagel and Rees (1996) is an accounting tool for measuring human impact on the earth in terms of the area of land and sea required to provide natural resources and to absorb waste. This is also a measure of social metabolism. The EF is one of the most popular biophysical measures of society-nature interaction. Although it has been revised and improved (Borucke et al. 2013), it has also proven very controversial (Giampietro and Saltelli 2014).

IE and mainstream EE have been criticized for being "black boxed" and apolitical (Newell and Cousins 2014). Both have some link to ecological modernization theory (Burkett 2010). Nonetheless, IE lies 
closer to the interests of capital since it challenges it less (Bunker 1996; Carpintero 2005), while EE aligns more with a critique of the bourgeois economy, is methodologically pluralist, and integrates multiple approaches such as biophysical accounting and institutional economics (Naredo 2015). Political ecology tries to explain and understand socio-political dynamics related to the production of nature. PE is a very rich field of study with several theoretical approaches and adopting a goal of social transformation (e.g. Marxist political economy, Foucaldian analysis, World-Systems theory, etc.) (Peet et al. 2010). In this regard, EE and PE have been interlinked, where biophysical accounting as an expression of use-values can be understood a landmark for unmasking some of the contradictions of capital and the monetary valuations that support capitalist interests.

Biophysical accounting, then, has to be merged with a political ecology analysis in order to reinforce the radical contestation of power (Delgado-Ramos 2015; Martínez-Alier 2011; Walker 2005). Latin American and Spanish ecological economists ${ }^{2}$ have been working hand in hand with political ecologists to the point that sometimes is difficult to establish the division between approaches, where most EE could be conceptualized as radical ecological economics (Barkin et al. 2012; Carpintero 2005). As M'Gonigle (1999) noted, with the institutionalization of EE and the advance of neoliberal trends in academia, the majority of international EE scholars writing in English have abandoned or avoided this critical dimension and the links with PE. Since those early warnings the situation has tended towards a greater de-politicization of mainstream ecological economics (Barkin et al. 2012; Burkett 2010; Carpintero 2013; Spash 2011). Biophysical accounting, however, has been adopted by major institutions such as the OECD and EUROSTAT.

PE scholars influenced by Marxist theory and from different social sciences have used the concept of metabolism, or the analysis of materials and energy flows, without using the term metabolism explicitly. They have studied the political economy of the historical production of the city, as an expression of uneven socioecological development (Swyngedouw 2006) and as a hybrid socio-natural entity; and analysed ecological unequal exchange from World-Systems theory (Bunker and Cicantell 2005; Hornborg 2007). Furthermore, the work of John B. Foster and colleagues has importance for the concept of social metabolism and the introduction of the concept of 'metabolic rift', which is rooted in Marx's understanding of the labor process. Political ecologists depart from an orthodox use of Marx, contributing not only to the reinforcement of the understanding of the ecological contradictions of capital but also to a renewed Marxist tradition (Foster 2000; Foster et al. 2010). Even though EE and PE share the same metaphor of metabolism (explicitly or implicitly), and despite some exceptions (Martínez-Alier 2011; Naredo 2010), both approaches seem to lack crossfertilization (Newell and Cousins 2014). Consequently, some scholars have suggested advancing towards a political-industrial ecology, coupling the biophysical accounting derived from IE with the critical political analysis from PE (Newell and Cousins 2015). But some political-industrial ecology is essentially an oxymoron, given IE's links to modernization and green capitalism (Bleischwitz et al. 2011). Some hybrids do already exist, developed by scholars in radical ecological economics or ecological economics from the ground up (Healy et al. 2013; Naredo 2010).

Working within the ecological economics of fisheries, Pauly and Christensen (1995) proposed a method for calculating the Primary Production Required (PPR) to sustain global fisheries, and ecological footprint (EF) calculations were applied to aquaculture (Folke et al. 1998; Kautsky et al. 1997). Since then, biophysical accounting has been used to calculate PPR (Watson et al. 2014), the EF of fishing (de Leo et al. 2014; Swartz et al. 2010), and the carbon footprint of seafood production uses Life Cycle Assessment (LCA) (Ziegler et al. 2012). Most of those works do not treat the political ecology of fisheries in any depth. Yet the fisheries crisis is a crystallization of the ecological contradictions of capital in relation to exploitation of the oceans over time. Some studies reject the argument of the 'tragedy of the commons' as the explanatory basis for understanding the crisis of the oceans, and instead they place commodification more centrally (Clausen and Clark 2005; Longo 2012; Longo et al. 2015).

\footnotetext{
${ }^{2}$ One of the first works fusing ecological economics and political ecology was Extremadura saqueada coordinated by José Manuel Naredo and developed to reinforce the arguments of the anti-nuclear struggle in Extremadura (Spain). It is important to note that this book was self-managed and published within the anarchist and anti-Francoist publisher Ruedo Ibérico (Naredo et al. 1977).
} 
In the following subsections I outline the methods used for the calculation of total catch and the fishing footprint. These methods build on gray literature, my fourteen years of experience as a small-scale fisherman, and a whole life spent living in a fishing port in Mallorca. Academic interviews were conducted different stakeholders (e.g. fishermen, fishing managers, seafood saleswomen, restaurant and hotel managers, and recreational fishers).

\section{Methods and data sources}

The accounting method ${ }^{3}$

a) Total fish catch

It is generally accepted that official statistics report only a fraction of total fish catches, and hence new methods have been developed to estimate them more adequately (Pauly et al. 2014). Total fish catches (TC) is the sum of total landings (TL) plus total discards (TD) ( Coll et al. 2014).

$$
T C_{S, F}=\sum_{S=1, F=1}^{S, N}\left(T L_{S, F}+T D_{S, F}\right)
$$

TL for S species and the F-number of fishing fleets is composed of official landings (OL) and unreported landings (UL). I developed a database reconstructing official fish landings from historical statistics. Second, detailed data on species landings by fishing fleet typology and gear (i.e. trawling, purse seining and artisanal) was selected for anchor time-points. Second, departing from the data of total official landings for the whole period, the composition of official landings by species was estimated through lineal interpolations of the known catches by species of the anchor points. Anchor points were chosen because they were representative of the period and depending on the availability of statistical sources. Third, UL is a sort of a 'black box' composed of black market catch (BM), unregistered artisanal catch (AC), recreational fishing (RF), and personal fish consumption (PC).

$$
\mathrm{TL}_{\mathrm{S}, \mathrm{F}}=\sum_{\mathrm{S}=1, \mathrm{~F}=1}^{\mathrm{S}, \mathrm{N}}\left(\mathrm{OL}_{\mathrm{S}, \mathrm{F}}+\mathrm{UL}_{\mathrm{S}, \mathrm{F}}\right)=\left(\mathrm{OL}_{\mathrm{S}, \mathrm{F}}+\mathrm{BM}_{\mathrm{S}, \mathrm{F}}+\mathrm{AC}_{\mathrm{S}, \mathrm{F}}+\mathrm{RF}_{\mathrm{S}, \mathrm{F}}+\mathrm{PC}_{\mathrm{S}, \mathrm{F}}\right)
$$

Even though, illegal catches have been considered in other studies (Agnew et al. 2009), they cannot be accounted for in this article because an historical reconstruction would require a deeper investigation based on regulation schemes, official reports, oral sources, etc. TD includes overboard discards (D) by fleet typology and trophic level of discarded species; post-escape mortality (PM), which are those individuals that die underwater after escaping from fishing gears; and ghost fishing (GF), those trapped in lost or abandoned gears.

$$
\mathrm{TD}_{\mathrm{S}, \mathrm{F}}=\sum_{\mathrm{S}=1, \mathrm{~F}=1}^{\mathrm{S}, \mathrm{N}}\left(\mathrm{D}_{\mathrm{S}, \mathrm{F}}+\mathrm{PM}_{\mathrm{S}, \mathrm{F}}+\mathrm{GF}_{\mathrm{S}, \mathrm{F}}\right)
$$

b) Primary Production Required to Sustain Fisheries (PPR) as the ecological footprint of fishing

Once total catches (TC) are estimated, the PPR to sustain fisheries can be calculated following Pauly and Christensen's method, where CR is the conversion rate from fresh weight to dry weight; tl is the trophic

\footnotetext{
${ }^{3}$ For an expanded explanation of the methodology the following works are recommended: Coll et al. (2014) and Carreras et al. (2015).
} 
level of $\mathrm{i}$-species and $\mathrm{n}$ the number of species; and TE is the transfer efficiency among trophic levels (Pauly and Christensen 1995; Watson et al. 2014).

$$
\mathrm{PPR}=\sum_{\mathrm{i}=1}^{\mathrm{n}} \frac{\mathrm{TC}_{\mathrm{i}}}{\mathrm{CR}} \times\left(\frac{1}{\mathrm{TE}}\right)^{(\mathrm{tl}-1)}
$$

Trophic levels are taken from FishBase (Froese and Pauly 2014) and then they have been applied for calculating PPR for the selected anchor time-points, whilst results have been interpolated for the years between them and adjusted by overall official landings per year.

c) Total seafood consumption (TSFC) and ecological footprint of seafood consumption (EFSFC)

The calculation of TSFC is based on an MFA methodology where Total Materials Consumption (TMC) equals total fish catch (TC) plus aquaculture and fish imports, minus exports. Used domestic extraction (DE) is equivalent to OL and aquaculture (Aq); and unused domestic extraction (UDE) ${ }^{4}$ equals UL plus TD. Trade flows, imports (I) and exports (E), are composed of direct flows (dI, dE), coinciding with official reporting, and indirect flows that result from estimating discards associated with trade flows (iI, iE). Then, unused and indirect flows can be characterized as 'hidden flows.'

$$
\begin{gathered}
\text { TSFC }=[(\mathrm{DE}+\mathrm{di})-\mathrm{dE}]+[(\mathrm{UDE}+\mathrm{iI})-\mathrm{iE}] \\
=[(\mathrm{OL}+\mathrm{Aq}+\mathrm{dI})-\mathrm{dE}]+[(\mathrm{TD}+\mathrm{UL}+\mathrm{il})-\mathrm{iE}]
\end{gathered}
$$

Trade flows are converted into the PPR. In order to do so, due to the lack of available data on fish trade by trophic levels, a conversion factor (CF) is assumed equivalent to PPR/TR of Balearic fisheries. The ecological footprint of seafood consumption (EFSFC) equals the PPR needed to sustain fish consumption.

$$
\mathrm{EFSFC}=\mathrm{PPR}+(\mathrm{CF} \times(\mathrm{I}-\mathrm{E}))
$$

Lastly, the EF is compared to the Balearics marine biocapacity, to estimate the size of its impact on marine resources. Biocapacity is calculated taking into account the primary production (PP) of the marine area, an average of $116 \mathrm{gC} / \mathrm{m}^{2} /$ year for the western Mediterranean (Stambler 2014). Balearic territorial waters accounts for $2.89 \mathrm{TgC} /$ year. Finally, it should be underlined that this methodology differs slightly from the standard ecological footprint of fishing (Talberth et al. 2007) since here the yield and equivalence factors have not been used in the calculation of the ecological footprint and the 'no take zones' have not been subtracted from biocapacity. In consequence, the results are valuable in terms in comparing the evolution of the footprint over time, but they cannot be used to compare the results with those obtained from the standard methodology reported in global hectares.

\section{Data sources}

a) Fish landings, fishing fleet, aquaculture and the fish trade

Since the early years of the 20th century, authorities have reported fish landings. Annual Reports present data on fish landings by target species and province, among other data. Paradoxically, fishing statistics were interrupted when Spain entered into the EU (1986) until 1995. Nevertheless, the regional government of the Balearic Islands has collected this data since the late eighties.

\footnotetext{
${ }^{4}$ Briefly, MFA standard methodology defines used materials as those that enter into the economic system for processing or commodity consumption, while unused materials are those that go with the used ones, though they do not take the form of commodities and don't appear in official statistics. In fisheries unused materials are simply unregistered or unreported, but they can be part of the fisheries' business, and therefore used.
} 
Anchor time-points have been selected according to available sources, aiming to cover the period of analysis (1940-2012). Aquaculture in the Balearics started in the 1980s and was mainly the feeding of young fish to be exported (e.g. gilt-head brim and sea bass) and mussel farming, though its importance has been low. Finally, fish trade data reported has been collected from port authorities for the period between 1990 and 2012. Currently, fish trade data for the whole period is not available, but further research should focus on constructing a time series (Table 1).

\begin{tabular}{|c|c|c|}
\hline Concept & Years & Source \\
\hline \multirow{4}{*}{$\begin{array}{l}\text { Fish Landings (by species). } \\
\text { Anchor points }\end{array}$} & $\begin{array}{l}1940,1945,1946 \\
1949,1955,1956, \\
1960,1970,1972\end{array}$ & $\begin{array}{l}\text { Dirección General de Pesca Marítima. Estadística } \\
\text { de Pesca. Madrid: Ministerio de Industria y } \\
\text { Comercio }\end{array}$ \\
\hline & 1980, 1984 i 1986 & $\begin{array}{l}\text { MAPA. Anuario de Pesca Marítima. Madrid: } \\
\text { Ministerio de Agricultura, Pesca y Alimentación }\end{array}$ \\
\hline & 1999 & Lucas (2002) \\
\hline & From 2002 to 2012 & $\begin{array}{l}\text { Direcció General de Pesca. Govern de les Illes } \\
\text { Balears }\end{array}$ \\
\hline \multirow{2}{*}{$\begin{array}{l}\text { Fish Landings (Total). } \\
\text { Non anchor points }\end{array}$} & $1940-1987$ & INE. Anuario Estadístico de España \\
\hline & $1988-2001$ & $\begin{array}{l}\text { Direcció General de Pesca. Govern de les Illes } \\
\text { Balears }\end{array}$ \\
\hline Aquaculture & $1987-2012$ & $\begin{array}{l}\text { Direcció General de Pesca. Govern de les Illes } \\
\text { Balears }\end{array}$ \\
\hline \multirow{6}{*}{$\begin{array}{l}\text { Fishing fleet (vessels, GT, HP) } \\
\text { and fishermen }\end{array}$} & $1940-1960$ & $\begin{array}{l}\text { Dirección General de Pesca Marítima. Estadística } \\
\text { de Pesca. Madrid: Ministerio de Industria y } \\
\text { Comercio }\end{array}$ \\
\hline & 1970 & \begin{tabular}{|l|} 
Dirección General de Pesca Marítima. Flota \\
pesquera española en 31 de diciembre de 1970. \\
Ministerio de Industria y Comercio \\
\end{tabular} \\
\hline & 1980 & $\begin{array}{l}\text { Ministerio de Agricultura, Pesca y Alimentación. } \\
\text { Anuario de pesca marítima. }\end{array}$ \\
\hline & 1990 & Massutí (1994) \\
\hline & 1999 & Lucas (2002) \\
\hline & 2012 & $\begin{array}{l}\text { Ministerio de Agricultura, Alimentación y Medio } \\
\text { Ambiente. Ministerio de Agricultura, } \\
\text { Alimentación y Medio Ambiente. Características } \\
\text { técnicas de la flota por comunidad autónoma del } \\
\text { puerto de base. } \\
\text { Direcció General de Pesca. Govern de les Illes } \\
\text { Balears }\end{array}$ \\
\hline Trade & $1990-2012$ & $\begin{array}{l}\text { Autoritat Portuària de les Illes Balears (Statistical } \\
\text { Office). }\end{array}$ \\
\hline Energy (Fuel consumption) & $1998-2001$ & $\begin{array}{l}\text { 1998: Conselleria d'Economia, Agricultura, } \\
\text { Comerç i Indústria. Fax received 22/09/1999. } \\
\text { 2001: Conselleria de Medi Ambient, } 2004\end{array}$ \\
\hline Subsidized gas-oil price & $1998-2012$ & www.coag.org [accessed December 20 2014] \\
\hline Edible Fish Protein & 1989 & FAO (1989) \\
\hline
\end{tabular}

Table 1. Fish landings, fishing fleet, aquaculture, fish trade and energy data sources. 
b) Discards and unreported landings

The calculation of IUU (Illegal, Unreported and Unregistered) catch is problematic and it has been a main research target in the study of fisheries. Recent global estimates report a decrease of global discards, proclaimed as good news (Kelleher 2005), though this could be caused by a reduction of total catch, indicating an earlier decline of fish stocks than previously thought (Zeller and Pauly 2005).

From the literature I estimated discard factors by species, based on fishing gears, and other unreported removals. Then, discard factors and other removals factors were extrapolated across the whole period. Trawling discard estimates are based on Moranta et al. (2000) who studied decapod crustacean fisheries in the Balearics. Artisanal discard factors - trammel nets, longlines and purse seine - are calculated from Greek cases (Tzanatos and Somarakis 2007; Tsagarakis et al. 2012). Discards are considered in relation to the target species, and therefore trophic levels are distinguished. In general terms, by-catch species are from lower trophic levels than target species. Ghost fishing is estimated as 1 per cent of official landings, considering that these catches correspond to the average trophic level (Brown et al. 2005).

Black Market fishing (BM) is based on Carreras et al. (2015) who estimated it as 11 per cent of fish landings, and then discards related to BM were calculated. In this case, the trophic level of fish landings is estimated to be the average of landings, and discards related to BM landings is considered to be the same as the average of discards' trophic level. Black market activities have decreased with the incorporation of Spain into the EU and the subsequent 'modernization' of public administration, so assuming BM fishing has not changed over time, it is an underestimate. Personal fish consumption, which is the amount of fish that is consumed on board during the fishing day or the 'bag' that fishers take home, is estimated as $1.5 \mathrm{~kg}$ by fisher per fishing day (Coll et al. 2014), for an average of 118 fishing days per year (Maynou et al. 2014).

Finally, recent recreational fisheries studies in the Balearics inform estimates of this unreported activity, considering detailed taxon and trophic level (Grau, 2008; Morales-Nin et al. 2004; Morales-Nin et al. 2005). It is assumed an average recreational fish catch of $1.73 \mathrm{~kg} / \mathrm{capita} /$ year, multiplied by yearly numbers of fishers.

\section{The Balearic Islands: the tourist pearl of the Mediterranean}

The Balearic Islands are located in the Western Mediterranean and composed of 146 islets, but only four inhabited islands: Mallorca (3,603 $\left.\mathrm{km}^{2}\right)$, Menorca $\left(393 \mathrm{~km}^{2}\right)$, Ibiza $\left(569 \mathrm{~km}^{2}\right)$ and Formentera $\left(81 \mathrm{~km}^{2}\right)$ (Figure 1). Although it is the second smallest Spanish province by landmass, it has the second largest coastline length $(1,428 \mathrm{~km})$, after the Canary Islands $(1,553 \mathrm{~km})$. Balearics territorial water (12 nautical miles from the coastline) extend over $24,981 \mathrm{~km}^{2}$, and can be divided in the following sections: the coastal shelf, 0 $50 \mathrm{~m}$. isobath (9\%); the continental shelf, 50-200 m., (33\%); the continental slope, 200-400 m., (17.6\%); and the deep continental slope, 400-1,000 m. (39.5\%). After long social mobilizations and struggles against urbanization resulting from coastal tourism (Murray 2012; Rayó 2004) some natural coastal areas were protected from development, including the national park of Cabrera and sa Dragonera (Mallorca), es Grau (Menorca) and ses Salines d'Eivissa and Formentera, plus seven marine reserves (Figure 1). The total effective marine protected area accounts for $732 \mathrm{~km}^{2}$, representing $2.9 \%$ of the territorial waters, which is considered insufficient by scientists and environmentalists (Pastor 2007) ${ }^{5}$.

The conversion of the Balearics into one of the world's main tourist hotspots has built on its insular and Mediterranean environment, and its semi-peripheral position within Europe. This insertion into global capitalism through tourism has caused a radical socio-economic transformation (Murray 2012). Traditional marine and coastal activities have been replaced by the mass commodification of space. In the 2000s the Balearics hosted the largest number of hotels and marinas in Spain (Pons et al. 2014; Suárez and Martínez 2012), and was the second largest Spanish cruise destination (Garau 2006). Balearic hotel corporations are among the top hotel chains worldwide, holding substantial tourism-derived capital investment. Recently, most hotel investments have been abroad, especially in the Caribbean, where the firms' resorts and hotels have been involved in socio-ecological conflicts (Blázquez et al. 2011).

\footnotetext{
${ }^{5}$ Spatial Protected Areas (SPA) and Sites of Community Importance (SCI) are designated according to EU Nature Directives, but management plans have not been enforced. These spaces are basically 'protected on paper.'
} 
The archipelago's coastal areas have been radically transformed. Some $22.5 \%$ of the first 500 meters of the coastline was urbanized by the time the Spanish housing bubble peaked in 2005 (Murray 2015). Urban expansion along the coast was actually less intense than in other Spanish tourist regions, slowed by social protest and the implementation of more restrictive spatial planning policies (Blázquez et al. 2010). An island barrier effect also operated, diminishing capital investment relative to mainland coastal areas, which are connected through the continental road network to the rest of Europe and therefore easing construction costs and tourist mobility (Pons and Rullan 2014).

As can be seen in Figure 2, the advancement of tourism and post WWWII technological changes resulted in a simultaneous process of job losses in fishing and a reduced number of vessels, but with an increase in fishing fleet power. The tourism boom provoked commodification of beaches and ports, and also intense labor displacements from traditional activities, fishing and agriculture, to tourism and construction (Murray 2012). Although, most of the inhabitants of the Balearics currently work in the service sector 448,134 people, 73 per cent of the active population), 150,497 of these are in tourism-related activities, while the primary sector accounts only for 1.5 per cent (INE 2012). Back in 1955 most people worked in the primary sector - 73,746 people (40 per cent of the active population), and only 29 per cent in services (Alenyà 1984).

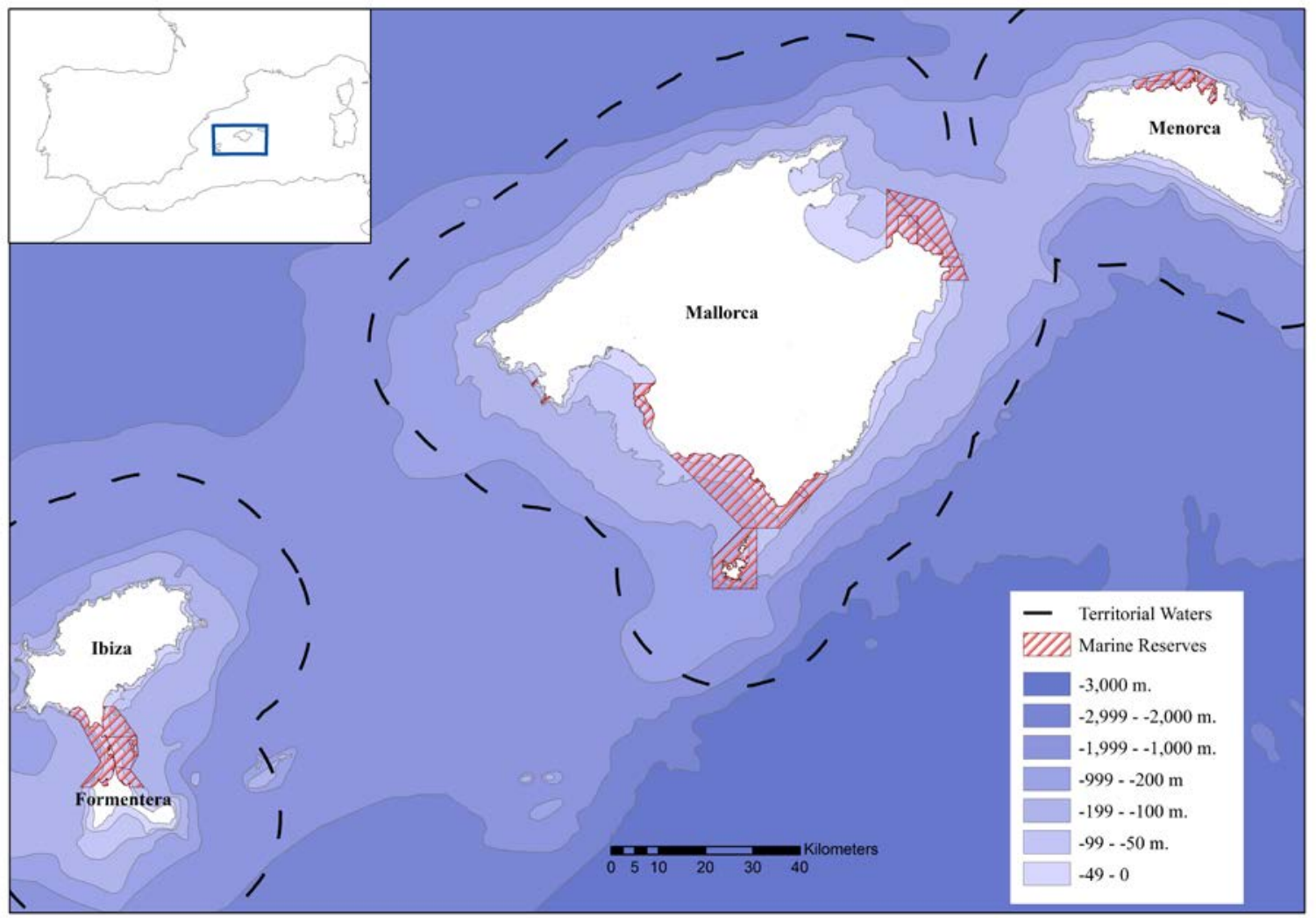

Figure 1: Localization and bathymetric map of the Balearic Islands. Source: own elaboration from Sitibsa.

Between the end of the Civil War (1939) and the acceptance of the fascist regime by capitalist powers (1959), the fishing fleet of the Balearics dropped from 1,523 (2,722 GT) to 1,057 vessels (2,733 GT). The reduction was because of a radical shift in fishing from sailing and rowing boats (73 per cent of the fleet in 1940) to motorized vessels, which accounted for 55 per cent of the fishing fleet and 86 per cent of the Gross Tonnage in 1960. This transformation, from wind power to motors and from small to large, was encouraged 
through the autarkic economic program launched by fascist authorities. Accordingly, the industrial fishing fleet was regulated to increase catch, at the expense of the artisanal fleet (Aspiroz 2003). Nevertheless, there was greater influence on the main Spanish fishing fleets in the Basque Country, Galicia and Andalucía (Compán 1975-1976).

The sources of fishing capital remained quite diverse, from local bourgeoisie investments to smuggling. Since the 1960s hoteliers have become the dominant capitalist class and they focused their investments in the hotel and construction sectors (Amer 2006). But with the economic transformation driven by tourism, fishing investments also became quite attractive due to their high returns, and novices bought boats. With the tourism boom, and especially from the mid 1970s, some fishers have become boat owners in their own right, and currently most of the fishing fleet belongs to family businesses (Velasco 1992).

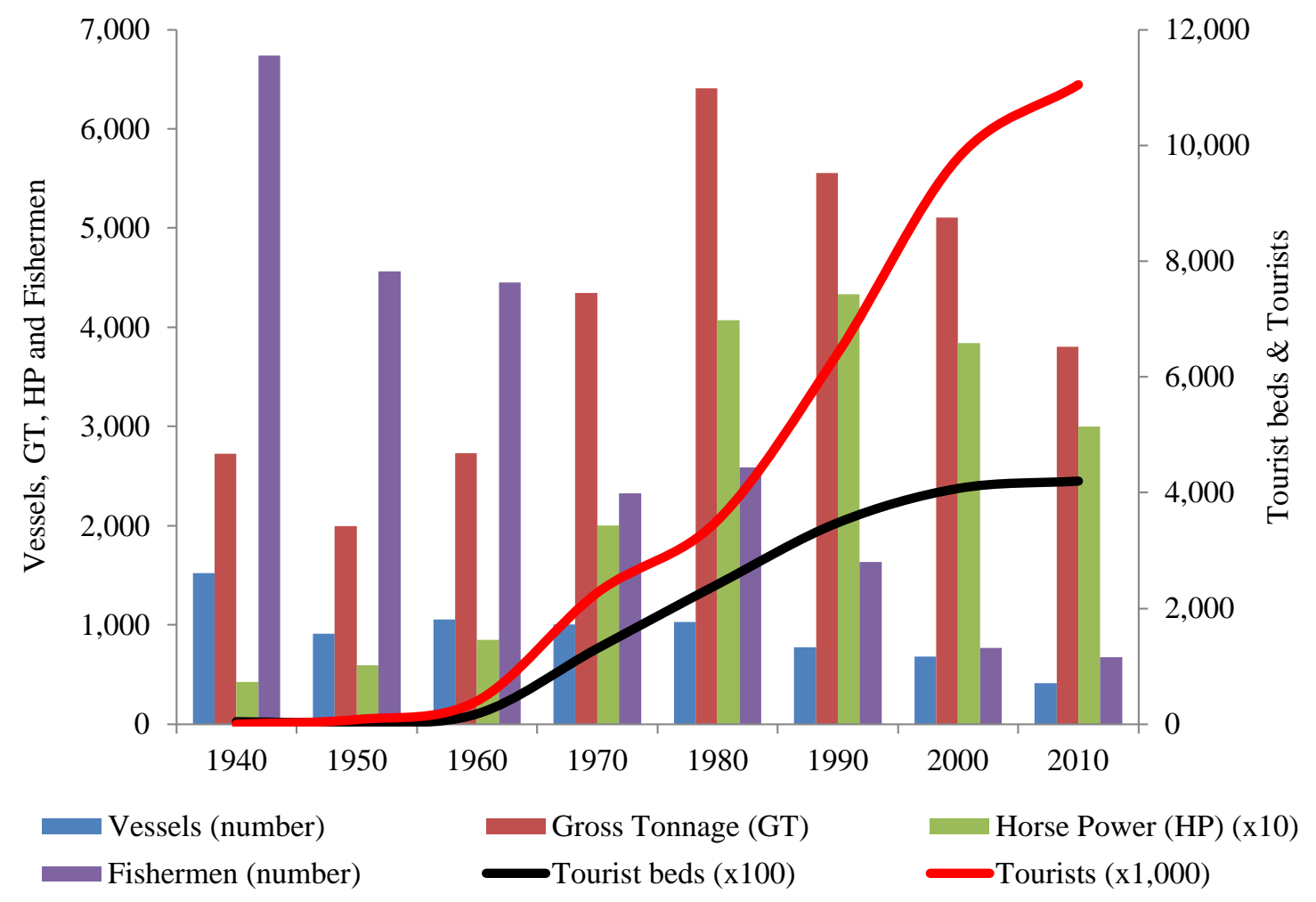

Figure 2: Fishing fleet, fishermen and tourism evolution in the Balearic Islands, 1940-2010. Source: Own elaboration based on: fishing data (Table 1) and tourism data (Murray 2012; Pons et al. 2014).

While fishing jobs dropped steadily, fishing capacity in terms of fleet power grew to a maximum of 49,200 HP in 1986, coinciding with the Spanish entrance into the EU (Velasco 1992). Subsequently, with the adoption of EU policies, the Balearics fleet has been reduced down to 337 vessels (29,155 HP) with 621 fishermen remaining in 2012. In contrast, despite the global crisis, the tourism industry, heavily supported by public authorities, reached 12.5 million tourists in 2012, with 422,000 tourist beds. 


\title{
5. Official fish landings: from the 2nd World War to neoliberal globalization
}

\author{
Official landings: from fish catches for the popular classes to tourism-driven fishing
}

During the Spanish Civil War and WWII (1936-1945), marine activities halted due to fuel shortages and the risk of sailing in the Mediterranean. However, during Franco's autarkic period (1939-1959), fascist authorities promoted fishing and fish consumption to alleviate nutritional deficiencies that could have led to hunger and social revolts against the regime (Ansola 2008). Accordingly, in the 1940s fish landings increased (Figure 3), especially of cheaper and widely consumed species like round sardinella (Table 2, Aspiroz 2003).

The eventual acceptance of the Spanish dictatorship by the capitalist bloc and the subsequent launching of a Developmentalist agenda, following the criteria of Bretton Woods institutions, resulted in public stimulus to the Spanish fleet. This was through the Fishing Fleet Protection and Renovation Act of 1961, and the Spanish fleet became one of the largest worldwide (Compán 1975-1976; Sinde 2008). Even though the Balearic fleet was not so important in national terms, it grew rapidly and drastic changes were introduced. Motorization facilitated fishing in deeper waters and tourism soon increased consumption and demand for high-price species (e.g. red shrimp). As already mentioned, in the sixties mass tourism shifted capital into this sector, from pre-tourist activities (e.g. the island textile industry) (Manera and Morey 2006). Members of the bourgeoisie diverted part of their surplus to fishing capital, which was in part another form of tourism investment given its influence on the coastal and maritime sectors (e.g. tourist boats, beach bars, etc.) (Murray 2013).

During the initial tourist boom, crustaceans were the most important target species with 261 tonnes landed in 1970, being ten times higher than in the 1940s. In the Desarrollismo stage deep-sea shrimp catches not only gained relevance in terms of fresh-weight (5.7\% of total landings), but they also became the main target species for their high market value (26.3\% of sales-value) (Table 2). In those years, fishermen from Catalan ports (e.g. Sant Carles de la Ràpita) went to Mallorca to fish for shrimp in summertime, coinciding with the high tourist season (Murray 2013).

Catches of tuna-like species soon increased drastically, accounting for 11.3 per cent of fish landings in fresh-weight. Non-Balearic purse seine and longline fleets operated, mainly from continental Spain and French Mediterranean ports, but fishing in Balearic waters. As a result, tuna-like species, but also elasmobranchs, were overfished (Mayol et al. 2000). In the 1970s and 1980s, overfishing had become a concern in the Balearics, for European hake or red shrimp in particular (Guijarro et al. 2010; Massutí 1973, 1989; Oliver 1993), and indeed across the Mediterranean Sea (Caddy and Griffiths 1991). One of the main indicators of this was the decrease of the size of the individuals and the increase in juveniles captured. Consequently, the Spanish government enacted regulations for the reduction of the Spanish fishing effort in the Mediterranean in the 1970s (Velasco 1992).

When Spain joined the EU (in 1986) led to the transposition of European policies, under a neoliberal doctrine (Fernández-Durán 2005). The Common Fisheries Policy (CFP) mandated fisheries conservation and promotion of international competitiveness of European fishing capitals at the same time (Pereira, 2002). It had serious effects on the fishing fleet of the Balearics. Since EU subsidies were given for fleet modernization and reduction, the artisanal fleet started to diminish (Oceana 2011a). On the other hand, the trawl fleet, heavily subsidized, increased its engines' power, even above the $500 \mathrm{HP}$ legal limit, and in order to maintain or increase fishing revenues it fished further and deeper waters. The number of fishers per boat decreased from an average of seven crew per trawl boat in the seventies to four or three in the mid nineties. Technology and fossil fuels replaced human labor (Oceana 2011b).

Since the mid 1980s official landings have decreased steadily to the point that in 2012, they were even lower than those of 1940 when most boats were propelled by wind and human effort. In parallel, revenues have also diminished abruptly and sales revenues in the mid 1990s fell to those of the late 1960s (Figure 3). The reduction of fishing sales value has been related to the effects of trade globalization, with the disconnection of biomass production and consumption (Erb et al. 2009) and the reduction of food prices due to trade liberalization and the adoption of the adjustment policies in the Global South as part of the neoliberal agenda (Magdoff and Tokar 2010). The higher cost of local fish compared to imported ones, which is related to higher production costs (e.g. insurance, hygiene, fuel, labor, technological gadgets, etc.), has been a key 
factor that explains the rapid increase of imports. The sales value of local fish in 1995 was 4,485 euros/t (2005 prices), while the value of international fish imports was slightly higher $(4,926$ euros/t). So, in the mid nineties the impact of trade globalization was not so dramatic. However, since this time trade globalization speeded up (Dicken 2015) and fish imports increased dramatically, having an important impact on the value of Balearic fish captures. In 2012 the local fish sales value, 5,546 euros/t (2005 prices), was 71.5 per cent higher than international fish imports. Moreover, the value of international fish imports in 2012, 3,233 euros/t (2005 prices), was 34 per cent lower than in the mid 1990s (Secretaría de Estado de Comercio 2015). Currently, tourism businesses (e.g. restaurants, beach bars, hotels, etc.) have some good local seafood products for attracting customers, but then they sell cheap imported fish to substitute the local ones in traditional cuisine. For instance, imported common lobster (Homarus gammarus) substitutes for the local spiny lobster (Palinirus elephas) in the preparation of traditional dishes that are offered to tourists. Jobs have been dramatically reduced due to the dismantling of the fishing fleet, particularly the artisanal one, the substitution of fish jobs by technology, and the ageing of fishers. A retired fishermen stated that "fishers from Senegal save us" (Mora, 2015), which means that young locals do not work anymore in the fishing sector and instead sub-Saharan immigrants are those who now are employed.

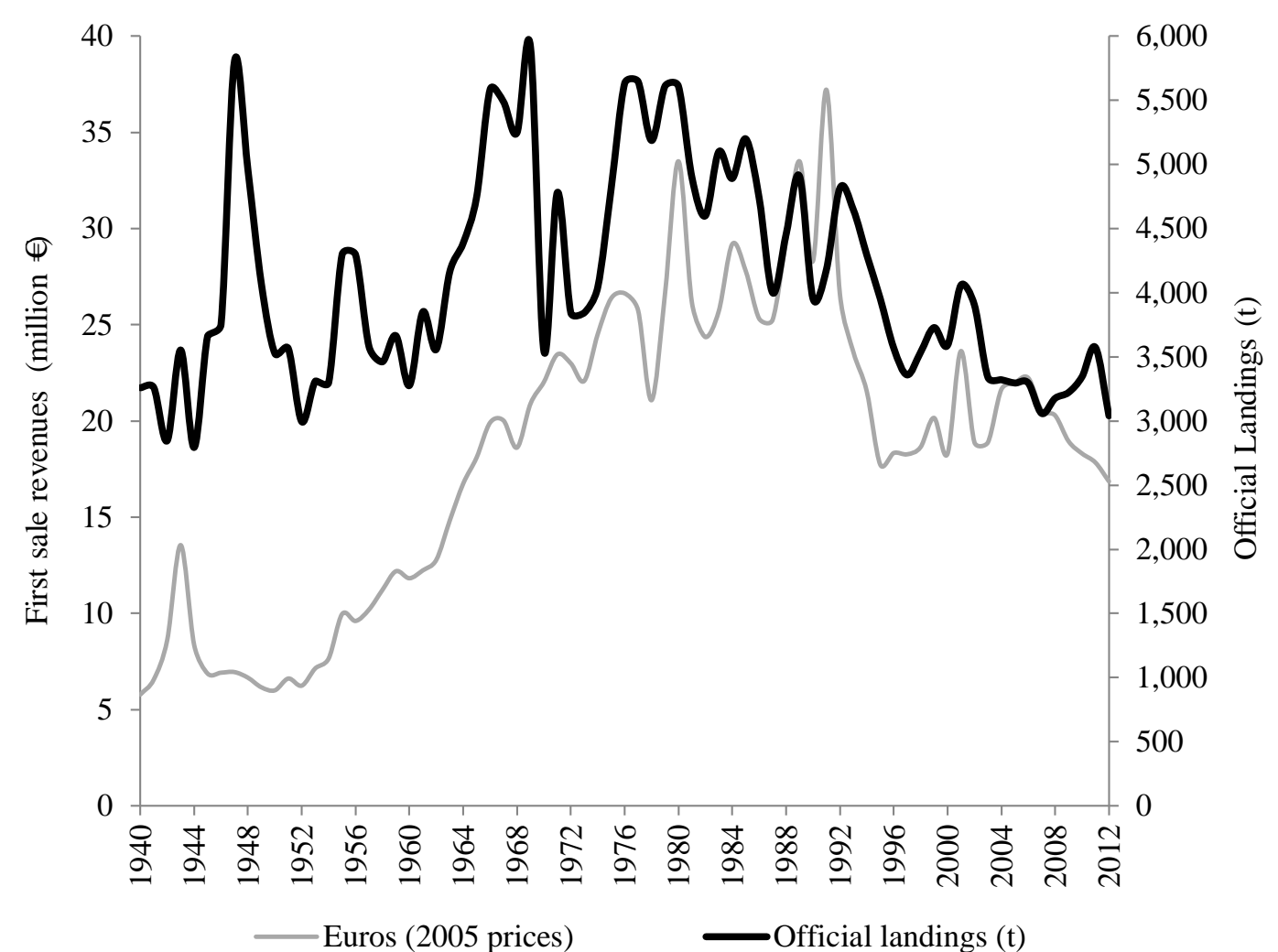

Figure 3. Official fish landings (tonnes) and first-sale revenues in 2005 prices, the Balearic Islands, 1940-2012. Source: see Table 1.

\section{Fishing for paying the fuel bill}

With the end of cheap oil, industrial fishing has become an extremely expensive activity, both in terms of energy and money. The Energy Return on Input (EROI) is a useful measure to analyze the efficiency of an economic activity in energy terms. In the case of food systems, the EROI can be calculated as the ratio between the edible-protein energy yield and the energy used to obtain it (Tyedmers 2004). Global fisheries have an EROI of 0.08, which is the amount of energy obtained from one unit of energy invested, though it 
should be underlined that fishery-derived protein is less energy intensive than other food production systems (Tyedmers et al. 2005).

Since the late 1990s, the Balearics' fishing fleet landed an equivalent to $7 \mathrm{Tj}$ /year of fish edible protein, while the estimated fuel consumption decreased slightly from $561 \mathrm{Tj}$ in 1998 to $420 \mathrm{Tj}$ in 2012 (Table 3). However, the fleet's fishing is quite an inefficient activity in energy terms with an EROI of 0.014, meaning that for every $\mathrm{Tj}$ of fuel consumed only $0.014 \mathrm{Tj}$ of fish edible-proteins are obtained (Table 3 ). These figures are very closed to shrimp fishing in the southwest Pacific, which has an EROI of 0.018 (Tyedmers 2004). This can be explained by the fact that deep-sea fisheries and trawling are predominant in the Balearics. Moreover, the energy analysis compares fishing value with the fuel cost. Since the rise of fuel prices in the first half of the 2000s, the cost of fuelling the fishing fleet has increased steadily and in 2012, when a liter of subsidized diesel was over one Euro, the fishing fuel bill was almost twice that of 1998. As a result, in 2012 the fuel cost was around 64\% of the value of fishing sales revenues (Table 3).

\begin{tabular}{|c|c|c|c|c|c|}
\hline \multicolumn{2}{|l|}{ Autarky } & \multicolumn{2}{|c|}{$\begin{array}{c}\text { Desarrollismo and transition to } \\
\text { neoliberalism }\end{array}$} & \multicolumn{2}{|l|}{ Neoliberalism } \\
\hline \multicolumn{2}{|l|}{ 1940-1959 } & \multicolumn{2}{|l|}{ 1959-1986 } & \multicolumn{2}{|l|}{$1986-2012$} \\
\hline \multicolumn{6}{|c|}{ Fresh-weight (percentage) } \\
\hline $\begin{array}{l}\text { Round sardinella } \\
\text { Sardinella aurita }\end{array}$ & 10 & $\begin{array}{l}\text { Tuna } \\
\text { Euthynnus alletteratus/Auxis } \\
\underline{\text { rochei }}\end{array}$ & 11.3 & $\begin{array}{l}\text { Sardine } \\
\text { Sardina pilchardus }\end{array}$ & 7.8 \\
\hline $\begin{array}{l}\text { Catshark } \\
\text { Galeus spp }\end{array}$ & 9.7 & $\begin{array}{l}\text { Sardine } \\
\text { Sardina pilchardus }\end{array}$ & 7.4 & $\begin{array}{l}\text { Picarel } \\
\text { Spicara smaris } \\
\end{array}$ & 7.6 \\
\hline $\begin{array}{l}\text { Red mullet } \\
\text { Mullus spp } \\
\end{array}$ & 6.1 & $\begin{array}{l}\text { Axillary seabream } \\
\text { Pagellus acarne }\end{array}$ & 5.7 & $\begin{array}{l}\text { Red Shrimp } \\
\text { Aristeus antennatus } \\
\end{array}$ & 5.9 \\
\hline $\begin{array}{l}\text { Bogue } \\
\text { Boops boops }\end{array}$ & 4 & $\begin{array}{l}\text { Red Shrimp/Soldier striped } \\
\text { shrimp } \\
\underline{\text { Aristeus }} \\
\underline{\text { antennatus/Plesionika spp }}\end{array}$ & 5.7 & $\underline{\text { Octopus spp }}$ & 5.3 \\
\hline $\begin{array}{l}\text { Mackerel } \\
\text { Trachurus trachurus } \\
\end{array}$ & 2.9 & $\begin{array}{l}\text { Red mullet } \\
\text { Mullus surmelatus } \\
\end{array}$ & 4.7 & $\begin{array}{l}\text { Mackerel } \\
\text { Trachurus trachurus } \\
\end{array}$ & 5.2 \\
\hline \multicolumn{6}{|c|}{ First sale monetary value (percentage) } \\
\hline $\begin{array}{l}\text { Red mullet } \\
\text { Mullus spp }\end{array}$ & 13.4 & $\begin{array}{l}\text { Red shrimp/Soldier striped } \\
\text { shrimp } \\
\underline{\text { Aristeus }} \\
\underline{\text { antennatus/Plesionika spp }}\end{array}$ & 26.3 & $\begin{array}{l}\text { Red shrimp } \\
\underline{\text { Aristeus antennatus }}\end{array}$ & 16.8 \\
\hline $\begin{array}{l}\text { Red Shrimp/Soldier } \\
\text { striped shrimp } \\
\underline{\text { Aristeus }} \\
\text { antennatus/Plesionika } \\
\text { spp }\end{array}$ & 11.7 & $\begin{array}{l}\text { Red mullet } \\
\text { Mullus spp }\end{array}$ & 7.1 & $\begin{array}{l}\text { Soldier striped shrimp } \\
\text { Plesionika spp }\end{array}$ & 7.7 \\
\hline $\begin{array}{l}\text { Catshark } \\
\text { Galeus spp } \\
\end{array}$ & 5.8 & $\begin{array}{l}\text { Hake } \\
\text { Merlucius merlucius } \\
\end{array}$ & 6.6 & $\begin{array}{l}\text { Lobster } \\
\text { Palinurus elephas } \\
\end{array}$ & 4.5 \\
\hline $\begin{array}{l}\text { Lobster } \\
\text { Palinurus elephas }\end{array}$ & 5.5 & $\begin{array}{l}\text { Tuna } \\
\text { Euthynnus alleteratus/ Auxil } \\
\text { rochei }\end{array}$ & 3.8 & $\begin{array}{l}\text { Squid } \\
\text { Loligo vulgaris spp }\end{array}$ & 4.2 \\
\hline $\begin{array}{l}\text { Squid } \\
\text { Loligo vulgaris spp }\end{array}$ & 3.0 & $\begin{array}{l}\text { Swordfish } \\
\text { Xiphias gladius }\end{array}$ & 3.6 & $\begin{array}{l}\text { Red scorpionfish } \\
\text { Scorpaena scrofa }\end{array}$ & 4.1 \\
\hline
\end{tabular}

Table 2: Top five fish landed species according to fresh weight (as percentage) and monetary value (as percentage) of Balearics' official landings. Source: see Table 1. 


\begin{tabular}{|c|c|c|c|c|c|c|}
\hline & \multicolumn{2}{|c|}{ Official Landings (OL) } & \multicolumn{2}{|c|}{$\begin{array}{c}\text { Fishing Fuel } \\
\text { consumption (FFC) }\end{array}$} & $\begin{array}{l}\text { Fuel Cost } \\
\text { Relative to } \\
\text { Revenue }\end{array}$ & $\begin{array}{l}\text { Protein Energy } \\
\text { Return on } \\
\text { Investment }\end{array}$ \\
\hline Year & $\begin{array}{c}\text { Million Euro } \\
(2005 \\
\text { prices }) \\
\end{array}$ & $\begin{array}{c}\text { Edible } \\
\text { protein, } \mathrm{Tj}\end{array}$ & $\begin{array}{c}\text { Million euro } \\
(2005 \\
\text { prices }) \\
\end{array}$ & $\mathrm{Tj}$ & $\begin{array}{c}\text { OL/FFC } \\
\text { (Euro } 2005 \\
\text { prices) }\end{array}$ & $\begin{array}{c}\text { OL/FFC } \\
(\mathrm{Tj})\end{array}$ \\
\hline 1998 & 18.64 & 7.07 & 6.99 & 561.71 & 0.37 & 0.013 \\
\hline 2012 & 16.83 & 6.78 & 12.63 & 420.68 & 0.64 & 0.014 \\
\hline
\end{tabular}

Table 3: Official Landings (OL) and Fishing Fuel Consumption (FFC) of the Balearics Fishing Fleet, 1998-2012. Source: Table 1.

\section{Opening the fisheries "black box": discards and unreported landings}

Generally, powerful narratives and defended positions are based on what is claimed to be 'real', and in this case, official statistics have played a key role in supporting the State and capital (Naredo 2015). There are official registered landings. However, the calculation of the total catch, and therefore accounting for hidden catches, is a fundamental element for estimating the ecological impact of fisheries or the ecological rift (Watson et al. 2014). It can be used as a counter-hegemonic argument against powerful and in this case official narratives. ${ }^{6}$ In the case of a tourist region, recreational fishing is extraordinarily important and accounts for a large proportion of the total captures in the 'black box', or hidden flows. Quantities of discarded fish and seafood may not differ from elsewhere.

Over the study period, the 'black box' was calculated as 126\% of official landings (OL) (Figure 4). Total discards have accounted for an average of $60.34 \%$ of OL. Those figures have been highly conditioned by the importance of trawlers in the total fleet, with $64.74 \%$ of landings and $41.5 \%$ of fishing power in terms of HP (Oceana, 2011b). Trawling catches increased in parallel with fleet motorization, passing from 6,681 HP in 1960 to a maximum of 19,952 HP in 1986. Since gears have not really changed, trawl discards differ according to target species and fishing depth, with an average of $70.58 \%$ of trawl OL and a mean trophic level of 3.345, mainly fish species. Most of fish discards (82\%) come from the continental shelf and slope, and only four fish species make up $62.97 \%$ of total discards: ling (Molva dipterygia), curled picarel (Centracanthus cirrus), catfish (Galeus melastomus) and boarfish (Capros aper) (Moranta et al. 2000). Recent studies demonstrate that a gear change from diamond shape mesh to square mesh, which is now mandatory in the EU, significantly reduces discards without affecting catches (Guijarro 2012; Ordines et al. 2006).

Small-scale fisheries, using gillnet, trammel net or longline, and purse seine fisheries are much selective than trawling. Nonetheless, artisanal fishing has decreased to the point that currently it accounts only for the $18.31 \%$ of official landings in the case of gillnet, trammel net and longline fisheries; and $20.20 \%$ in the case of purse seine fisheries (Oceana 2011a). Gillnet and longline discards make up 11.19\% of OL with a mean trophic level of 3.55, with $48.86 \%$ of discards being the three species picarels (Spicara flexuosa), scabbardfish (Lepidopus caudatus) and round sardinella (Sardinella aurita) (Tzanatos and Somarakis 2007). Purse seine fisheries are the most selective where mean discards are only $2.33 \%$ of landings with a mean trophic level of 3.064 (Tsagarakis et al. 2012).

Personal fish consumption and black market fishing was more important in the past than today now there are fewer fishers and less non-commoditized transactions. But tourist and recreational fishing has become one of the most significant threats to marine biodiversity (Font and Lloret 2014) and for the survival of small-scale fisheries in the Mediterranean (Lloret and Font 2013). In the early 21st century, recreational fishery was 38\% of OL at the Balearics, three times larger than artisanal landings (Figure 4).

Recreational fishing is competing for the same target species, which are already overfished, as small scale fishers (Morales-Nin et al. 2010). The sector is poorly regulated and controlled in comparison to

\footnotetext{
${ }^{6}$ The public diffusion through the media of the estimation of total discards at the Balearics generated a strong controversy involving the association of fishing companies (Olaizola 2015).
} 
professional fishing. While the newly reformed $\mathrm{CFP}^{7}$ pretends to restore European fish stocks to their maximum sustainable yield (MSY) through banning discards and establishing catch quotas, among other aspects, recreational fisheries were not included. Furthermore, in the context of the global crisis and austerity policies, the Balearic government has passed the regional fisheries Act that relaxes CFP guidelines in order to favor the interests of trawling and recreational fishing lobbies (Oceana 2012).

It is important to note that the monetary impact of recreational fisheries in Mallorca has been estimated as 1\% of its Gross Domestic Product (GDP), in 2009 (Morales-Nin et al. 2015), when GDP from professional fishing was three times lower and small-scale fisheries 21.87 times lower (CAMAT 2010; Oceana, 2011a). The expansion of tourism and leisure commodification encompasses more of human life and nature, and recreational fishing has become an important capital accumulation activity, in a different way to the 1960s when the tourism boom was met by commercial interests. Local authorities encourage recreational fishing, arguing that it generates higher value than the commercial sector. Recreational fishers, who are newcomers in the fishing sector, are displacing ageing artisanal fishers who suffer more from fish imports, increasing production costs and low local fish prices (e.g. 1986 fish price was 5.34 euros/t in 2005 prices, and in 2012 it was 5.55 euros). Ports are being converted into marinas, with speedboats and yachts displacing traditional small wooden boats. This dynamic can be conceptualized as marine and coastal gentrification (Blázquez 2013; Morell and Franquesa 2011; Vives 2011).

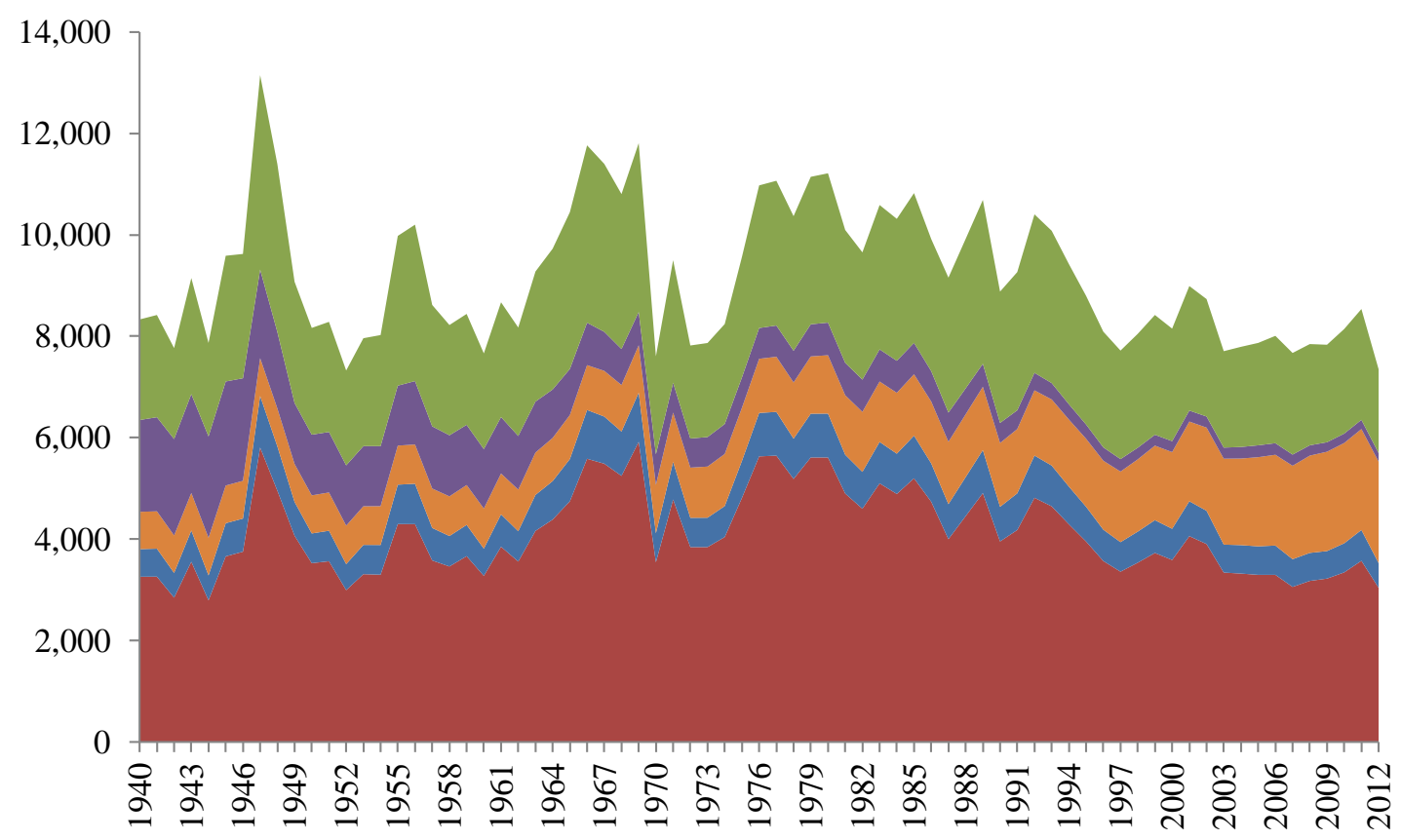

- Official Landings $\square$ Black Market $\square$ Recreation Catch $\square$ Personal Fish Consumption $\square$ Total Discards

Figure 4. Total fish catch (TC) in Fresh Weight (t) in the Balearic Islands, 1940-2012. Source: own elaboration according to section 2.

The study of regional scale social metabolism over long periods, applying methodologies such as the ecological footprint of consumption or material flow accounting, is still controversial, mainly due to data limitations, especially for trade statistics (Carpintero 2015; Sastre et al. 2015). For this reason, in the next

\footnotetext{
${ }^{7}$ Regulation (EU) 1380/2013 of the European Parliament and of the Council of 11th December 2013 on the Common Fisheries Policy. For a critical review see: http://cfp-reformwatch.eu/ [accessed January 20 2015].
} 
sections I make an analysis of the ecological footprint for the whole period, 1940-2012, followed by the ecological footprint of seafood consumption narrowed for a shorter period that coincides with the neoliberal period (1990-2012). The latter analysis is relevant for understanding the drastic transformation of fisheries since the nineties, when the Spanish economy experienced a radical change with a general restructuring under the neoliberal doctrine. In Spain, there was a radical shift from before entrance into the EU (1986) when domestic fish captures were much larger than fish imports (4.4 times larger in 1986) to the subsequent years when fish imports became much larger than the domestic fish catches (3 times larger in the peak of the bubble, 2007) (Carpintero 2005, 2015; Infante-Amate et al. 2015). As a consequence of the 'modernization' of Spanish capitalism, Spain has passed from being a net biomass exporter to a net biomass importer, and therefore its socio-ecological conflicts related to its food footprints have been displaced to other spaces (Carpintero 2005, 2015). Accordingly, the Balearic case could be conceptualized as an extreme example of this transformation due to the reinforcing effect of tourism, where since the middle of the 20th century food consumption has shifted from being based on domestic products to imported ones (Murray 2012).

\section{Primary production required to sustain fish catches (1940-2012), and the ecological footprint of seafood consumption in the neoliberal period (1990-2012)}

The ecological footprint of fishing: Primary Production Required to sustain fish catches as an expression of the metabolic rift

...in modern agriculture, as in urban industry, the increase in the productivity and the mobility of labor is purchased at the cost of laying waste and debilitating labor-power itself. Moreover, all progress in capitalist agriculture is a progress in the art, not only of robbing the worker, but of robbing the soil; all progress in increasing the fertility of the soil for a given time is a progress towards ruining the more long-lasting sources of that fertility (Marx 1990: 638).

And so, following Marx, modern fisheries have been based on robbing the sources of fertility of the oceans. Accordingly, the Primary Production Required to sustain fisheries can be seen as an expression of the expanding metabolic rift related to fisheries, because the more biomass is extracted species reproductive capacity is lowered, and therefore the deterioration of ecosystems is higher.

The estimates of primary production required to sustain Balearic fish catches (PPR) present a pattern that differs notably from total fish catches (TC). Total catches show a saw-like trend over time, with an increase in the mid 1960s (over 10,000 t), continuing except for the crisis in the early 1970s until the late 1980s, and then decreasing to values below 10,000 t (Figure 3). But the PPR was over 1 TgC to sustain peaks in the late 1970s and early 1980s; 30\% above the Balearic ocean's biocapacity. The high trophic level of species landings (mean trophic level 1980: 3.77, including tuna-like fishes and some species of sharks) and catch size explain that peak. PDR was static between 1940 and the early 1960s when landings were mainly for local consumption and from lower trophic levels (mean trophic level 1940: 3.39); and again from the early 1990s when fish landings decreased and the trophic level also fell (mean trophic level 2012: 3.53) due to overfishing of large pelagic fish. Due to overfishing, fish size was also reduced (Quetglas et al. 2012).

Hence, Balearic catches reflect fishing down the food web at a global scale (Pauly and Palomares 2005), also seen in the nearby Catalan sea (Coll et al. 2008). This results in the reduction of predators and the increase of prey, and short life and rapid growth species like jellyfish and cephalopods (Coll et al. 2008). The largest ecological footprint of fishing in the Balearics in the late 1970s coincided with the peak of Mediterranean fishing as a whole, while the Iberian coastal waters reached their peak between the mid 1960s and mid 1970s (Watson et al. 2014). The ecological footprint of fishing in the Balearics in the early 2000s averaged $16.04 \%$ of its biocapacity, being significantly smaller than the southern Catalan sea (36.1\%) (Coll et al. 2006), but higher than the Italian fisheries footprint (9\%) (de Leo et al. 2014). 
The ecological footprint of seafood consumption in the neoliberal period (1990-2012)

The estimation of fish consumption was developed only for the period 1990 to 2012, due to data limitations. However, this period covers a crucial span of time characterized by the adoption of EU fisheries policies and the economic boom from the Spanish financial and housing bubble and then later economic crisis. During this period, fish consumption was much larger than domestic catches, meaning imports supplied consumption. Direct fish imports went from 3.05 times the official landings in 1990 to 10.78 times in 2007, coinciding with the peak of the Spanish economic boom (Figure 5). The Balearics are an extreme case where 98.5\% of seafood consumption was fulfilled through imports in 2011 (Figure 5). This compares to 56\% across Spain and Spain and the EU27 countries where 48\% of the fish consumption was satisfied with catches in non-EU waters (NEF 2014).

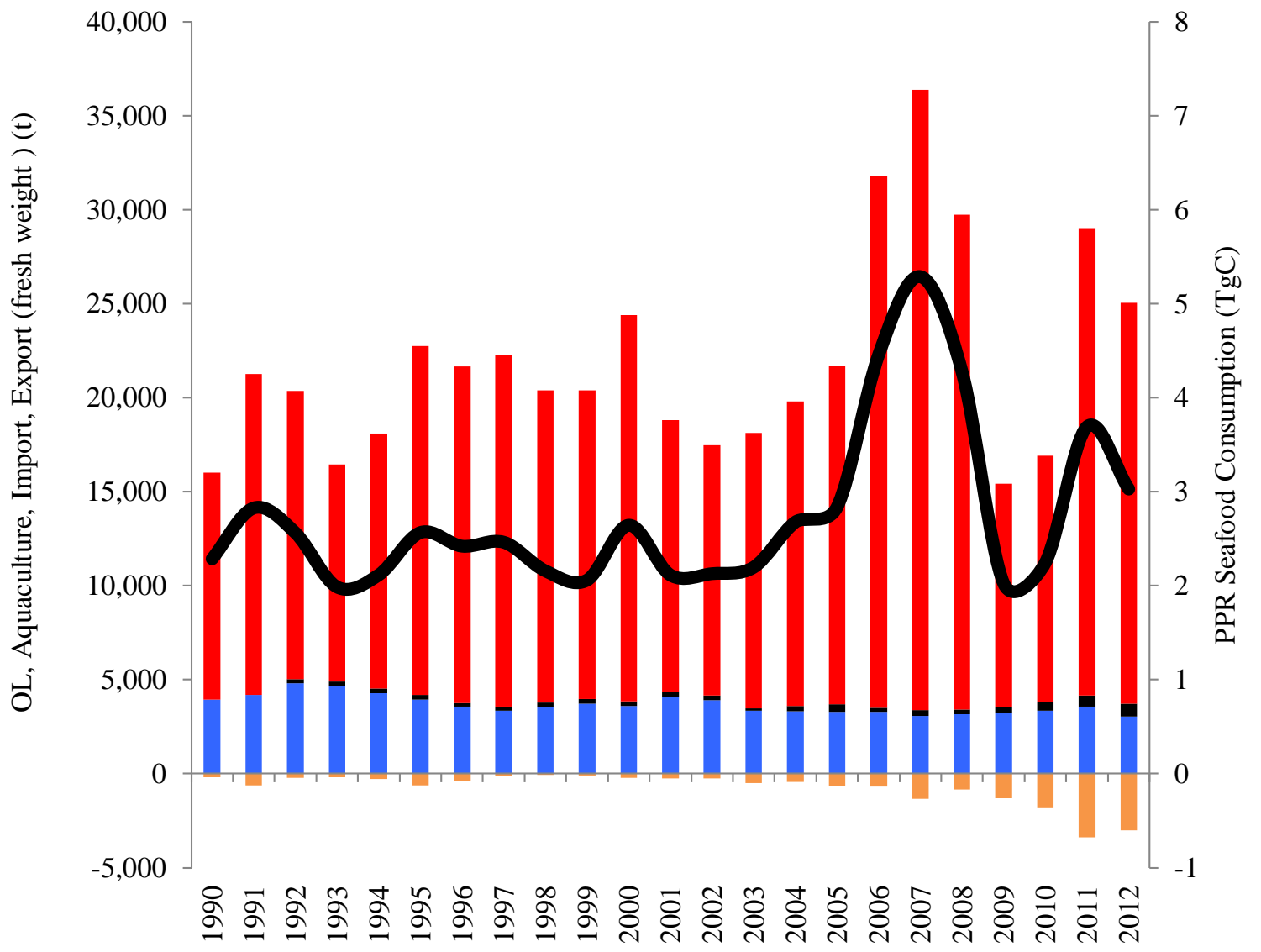

Official Landings

Aquaculture

Imports

Exports

$\longrightarrow$ PPR of Seafood Consumption

Figure 5: Official landings, aquaculture, imports and exports in fresh-weight $(\mathrm{t})$ and the ecological footprint of seafood apparent consumption (TgC) at the Balearic Islands, 19902012. Source: own elaboration following section 3.

The EU's fisheries policies attempt to preserve fish stocks, but they collide with trade policies that promote global ocean grabbing, displacing the ecological footprint and socio-ecological conflicts to distant waters (Bennett et al. 2015; Mulazzani and Malorgio 2015; Pedersen et al. 2014). Furthermore, the Spanish fleet is a major actor in fishing conflicts worldwide, fishing extensively in distant-waters (Balata et al. 2014). 
Attacks by Somali pirates on Spanish fishing boats have been reported in the mass media, and some fishing boats including those owned by Vidal Armadores were on a blacklist for fish piracy (Kaplam 2012).

Fish consumption rose from 15,826 $\mathrm{t}$ in 1990 to 35,040 $\mathrm{t}$ in 2007 in the Balearics, a clear expression of an economic boom. The expansion of consumption in Spain was driven by the financialization of everyday life, backed by the housing bubble, driving the so-called "richness effect" (López and Rodríguez 2010). Consumption was also strengthened by tourism demand (Murray 2012). After the 2007 global financial crisis fish consumption dropped significantly. In 2011 it started to grow again along with island tourism (Figure 6). This was a collateral effect of the Arab Spring with the diversion of tourists from Northern Africa to the archipelago (Murray 2012).

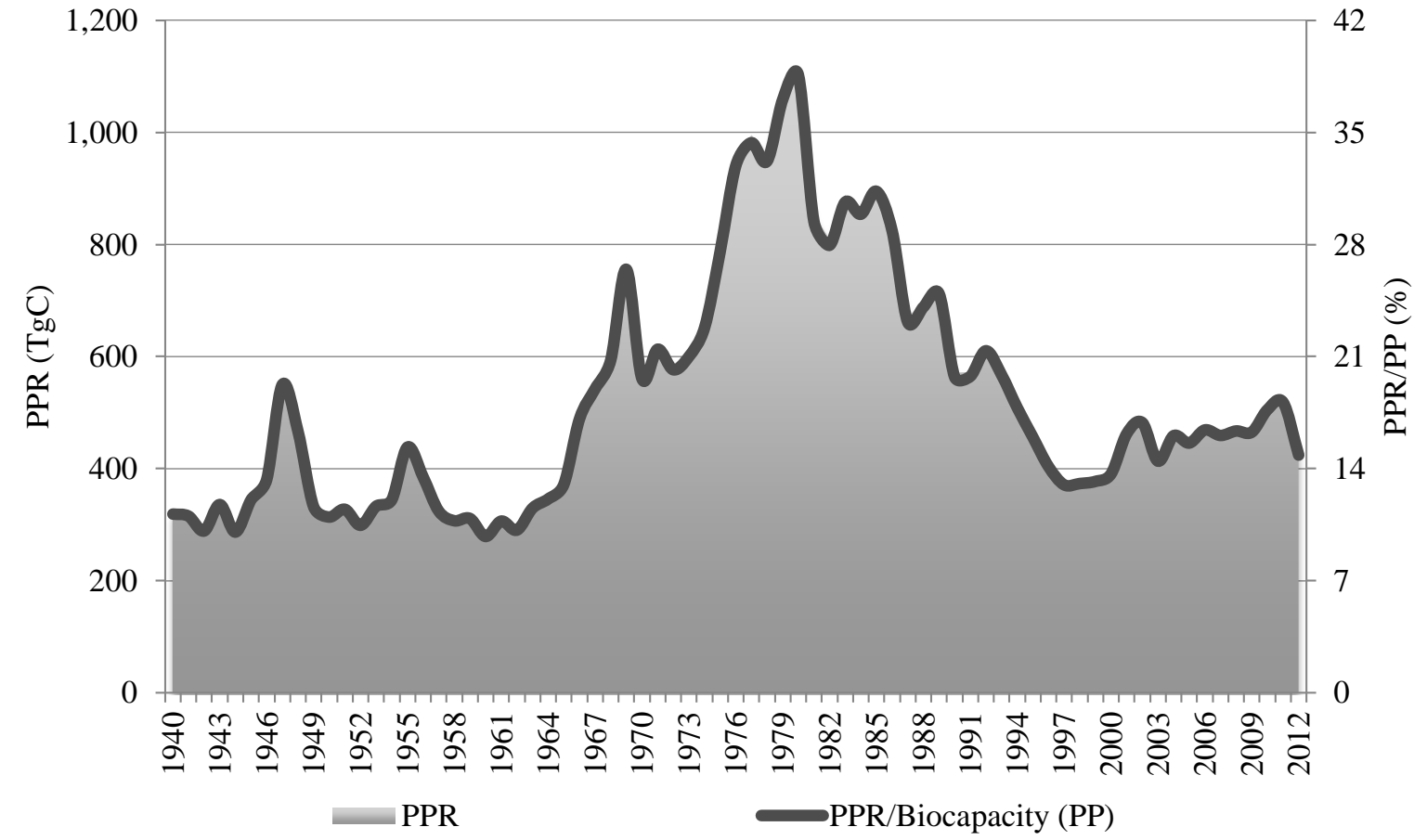

Figure 6: Ecological footprint of fishing or PPR (TgC) and PPR/Biocapacity (PP) (percentage) for the Balearic Islands, 1940-2012. Source: own elaboration according to section 2.

The analysis of fish imports is quite problematic since much comes from ports on the Spanish Mediterranean coast, especially from Barcelona. The port of Barcelona functions as a hub of many commodities that are redistributed to and from other locations, as with Rotterdam in the North Sea: the 'Rotterdam Effect' (Adriaanse et al. 1997). Traded fish species may have been caught by the Spanish fleet in distant fisheries but then landed in Spain and traded as Spanish goods. This makes it difficult to determine their origin. Some imported fish products are also processed in Spain and sold as Spanish. According to interviews with restaurant and fish-market managers in tourist ports, most of the fish sold is imported and within those imports some species from distant waters can be identified such as: shrimps from Northern Africa, lobsters from Canada and Cuba, African hake, prawn from Argentina, panga from Indonesia, and salmon from Norway, among others. Nevertheless, this requires a much deeper analysis than can be captured by material flow analysis which relies on trade statistics. Limitations on data sources could be overcome by a more eclectic approach, focusing on a limited number of species, but using a commodity biographies approach. This would follow fish products from production to consumption (Longo 2011; Sauguin 2014). 
The ecological footprint of seafood consumption at the Balearics grew from 2.28 TgC in 1990 to a maximum of 5.28 TgC in 2007 and then, with the economic crisis, decreased to 2.02 TgC in 2009 (Figure 6). This implies that biocapacity to satisfy those biomass requirements was insufficient, rising from $78.89 \%$ of Balearics primary production in 1990 to a peak of 182.5\% in 2007 (Figure 5 and Table 4). This large footprint (satisfied mainly via imports) explains why Balearics fisheries are less exploited than other Mediterranean regions (Quetglas et al. 2013). High tourism revenues compensate for a trade deficit and fish imports (Murray 2012). In conclusion, the ecological footprint of seafood consumption in the Balearic Islands during the neoliberal period illustrates the functioning of the capitalist food system based on the logics of unequal ecological exchange (Hornborg 2012; Magdoff and Tokar 2010). Socio-ecological conflicts have been displaced elsewhere (Martínez-Alier 2011). Accordingly:

...a sociometabolic perspective shows that capital accumulation does not take place on its own, and is not only based on the exploitation of Labor and technical change. Industrial capitalism advances into commodity frontiers because it uses more and more materials and energy, produces more and more waste, and thus undermines not only its owns conditions of production but the conditions of existence of peripheral peoples, who complain accordingly (Martínez-Alier 2007: 234).

\begin{tabular}{|c|c|c|c|c|}
\hline & & 1990 & 2000 & 2012 \\
\hline \multirow{5}{*}{$\begin{array}{l}\text { Direct } \\
\text { Flows } \\
\text { (Fresh } \\
\text { weight) }\end{array}$} & Official Fish Landings (t) & 3,955 & 3,590 & 3,041 \\
\hline & Aquaculture (t) & 0 & 267 & 683 \\
\hline & Imports (t) & 12,064 & 20,552 & 21,324 \\
\hline & Exports $(\mathrm{t})$ & 193 & 218 & 3,026 \\
\hline & Fish Consumption (t) & 15,826 & 24,190 & 22,021 \\
\hline \multicolumn{2}{|c|}{$\begin{array}{l}\text { Hidden Flows of Fish Consumption - Fresh } \\
\text { weight }(\mathrm{t})\end{array}$} & 9,509 & 15,851 & 18,859 \\
\hline \multicolumn{2}{|c|}{ TFC- Fresh weight (t) } & 25,335 & 40,041 & 40,880 \\
\hline \multicolumn{2}{|c|}{$\begin{array}{l}\text { EFFC - PPR to sustain Fish Consumption } \\
\text { (TgC) }\end{array}$} & 2.28 & 2.64 & 3.02 \\
\hline \multicolumn{2}{|c|}{ PPR/Biocapacity (PP) (\%) } & 78.89 & 91.22 & 104.50 \\
\hline
\end{tabular}

Table 4. Total fish consumption (TFC) and the ecological footprint of fish consumption (EFFC) for the Balearic Islands, 1990-2012. Source: own elaboration according to section 2.

\section{What's next? Blue capitalism as a new accumulation strategy}

Some scholars and multilateral institutions such as the OECD, UNEP and World Bank have proposed extending the logic of capital into a "blue ocean strategy" (Kim and Mauborgne 2005) or a "blue economy" (Pauli 2010; Pedersen et al. 2014; The Economist 2015). The ocean is taken to be an almost infinite and open space for capital innovation, through green technology, and offering business opportunities. As the neoliberal agenda has been reinforced in the current global crisis, geopolitical and economic conflicts are expected to increase due to struggles for 'what is left', and marine resources will undoubtedly be further appropriated (Brich and Mykhenko 2010; Klare 2012). The Catalan ecologist Ramon Margalef (1992) highlighted this contradiction between these marine hopes and resource extraction difficulties. The Arctic is one such frontier. The BGS coincidentally follows the myth of marine abundance that existed during the first years of Franco's Fascist dictatorship (Ansola 2008).

The European Commission (EC) has launched a Blue Growth Strategy (BGS) ${ }^{8}$ with the following assumptions: ports and coastal communities are centers for new ideas and innovation, rapid technological change permits working offshore in ever-deeper waters, land and freshwater resources are finite, and

\footnotetext{
${ }^{8}$ Blue Growth Strategy [accessed January 20 2015].
} 
humanity needs to deploy offshore renewable energy and expand marine transport in order to reduce greenhouse gas emissions (EC 2012). Coastal tourism, aquaculture, biotechnology, blue energy and offshore mining are part of a blue economy, and these are variously supported by European powers.

As one modality of "Green capitalism" (Fairhead et al. 2012), "Blue capitalism" is an accumulation strategy based on the commodification of nature (Pedersen et al. 2014; Smith 2010). The sea is seen as a space for implementing the logics of capital through the expansion of property rights, financialization, and accumulation by dispossession of substantial resources. In the Balearic Islands, the capitalist class has followed elements of the BGS through different coastal tourism and proposed offshore oil prospecting projects. Using the economic crisis as a pretext, the Balearic Islands conservative party (in government 20112015) deployed a package of regulations to facilitate a new round of tourism coastal development - new resorts, the renewal of old ones, the privatization of public space, and even the privatization and transformation of small ports into marinas. Some ports were to be adapted for cruise tourism (Artigues et al. 2014; Hof and Blázquez 2015).

The bursting of the housing bubble, expensive fossil fuels and more than five million unemployed people across Spain has also resulted in a boom in mining projects. Most of these, especially those involving fracking technology, have been controversial (Martín-Sosa 2015). New offshore gas and oil projects have been promoted, like the Castor Project developed in Tarragona (Northeast Spain) by ACS (one of the largest Spanish construction corporations) (Beizsley 2015). Offshore oil and gas drilling has expanded, particularly in the Canaries and Balearic Islands.

Back in 2001 the US Geological Survey had estimated that across an area of 250,000 $\mathrm{km}^{2}$ in the Western Mediterranean, there could be 250 million barrels of oil and 360 billion cubic meters of gas. Reserves lie 2,500 meters below sea level but 5,000 meters below the sea floor. No company was interested in 2001 (Pujol 2001). But in 2011, the Scottish corporation Cairn Energy obtained licenses from the Spanish Government for prospecting and drilling in the Balearics, eased by poor regulation. Multiple actors opposed the plans (Figure 7). They were led by the large hotel transnationals on the islands (e.g. Meliá Hotels International, Barceló, Riu, Fiesta, Iberostar, etc.), who argued against threatening the golden hen of tourism with an oil and gas industry (Hosteltur 2014). Social movements were also mobilized across Spain. ${ }^{9}$ The conflict erupted just before the regional and municipal elections. The conservative party, threatened in the polls, halted prospecting and Cairn Energy closed its Spanish offices (Planeles 2015). On the other hand, tourism capital and financial capital has concentrated in a new round of touristification along the Spanish coasts (Murray 2015).

\section{Conclusions}

Since the Balearics are a centerpiece for global tourism, the transformations of coastal and island spaces over time, and the effect on the fishing sector that was once very important to the islands, are emblematic. This study has shown how fusing ecological economics accounting methods with political ecology can inform the historical analysis of capitalism. A radical reading of social metabolism would benefit from merging both approaches, and Naredo (2015) is a point of reference. ${ }^{10}$

Despite some excellent proposals (Foster et al. 2010; Hornborg et al., 2007; Martínez-Alier 2011; Naredo 2010), there is an important division between the social metabolism accounting approach and political ecology (Fischer-Kowalski and Haberl 2007; Heynen et al. 2006). Fisheries research rarely combines the two approaches. There is a large amount of work done from an ecological economics or bioeconomics perspective (Watson et al. 2014), and within the political ecology and political economy framework (Campling 2012; Mansfield 2004). A better critical understanding of social metabolism of fisheries requires bridging both perspectives (Longo et al. 2015). The approach of Saguin (2014) in Metro Manila (Philippines) is useful, as is an analysis of the Mediterranean Bluefin tuna used for the production of global sushi (Longo 2012). This sort

\footnotetext{
${ }^{9}$ Multiple social movements have opposed prospecting: Al-liança Mar Blava in Ibiza, Plataforma Balears Diu No, Plataforma Marea Blava Mallorca and Menorca diu No.

${ }^{10}$ José M. Naredo published his work in 1987 (reprinted 2015). This was one of the first proposals for fusing multiple approaches in the study of human-nature dialectics, and the same year that Joan Martínez-Alier published his book Ecological economics: energy, environment and society. Naredo and Martínez-Alier shared thoughts and writings when they collaborated with the anarchist and anti-francoist journal Cuadernos del Ruedo Ibérico in Paris in the late sixties and early seventies (Forment 2000).
} 
of research associates fish consumption with distant-waters fishing, specifying fish trade taxon and origin, and the social conflicts embedded within fish commodities.

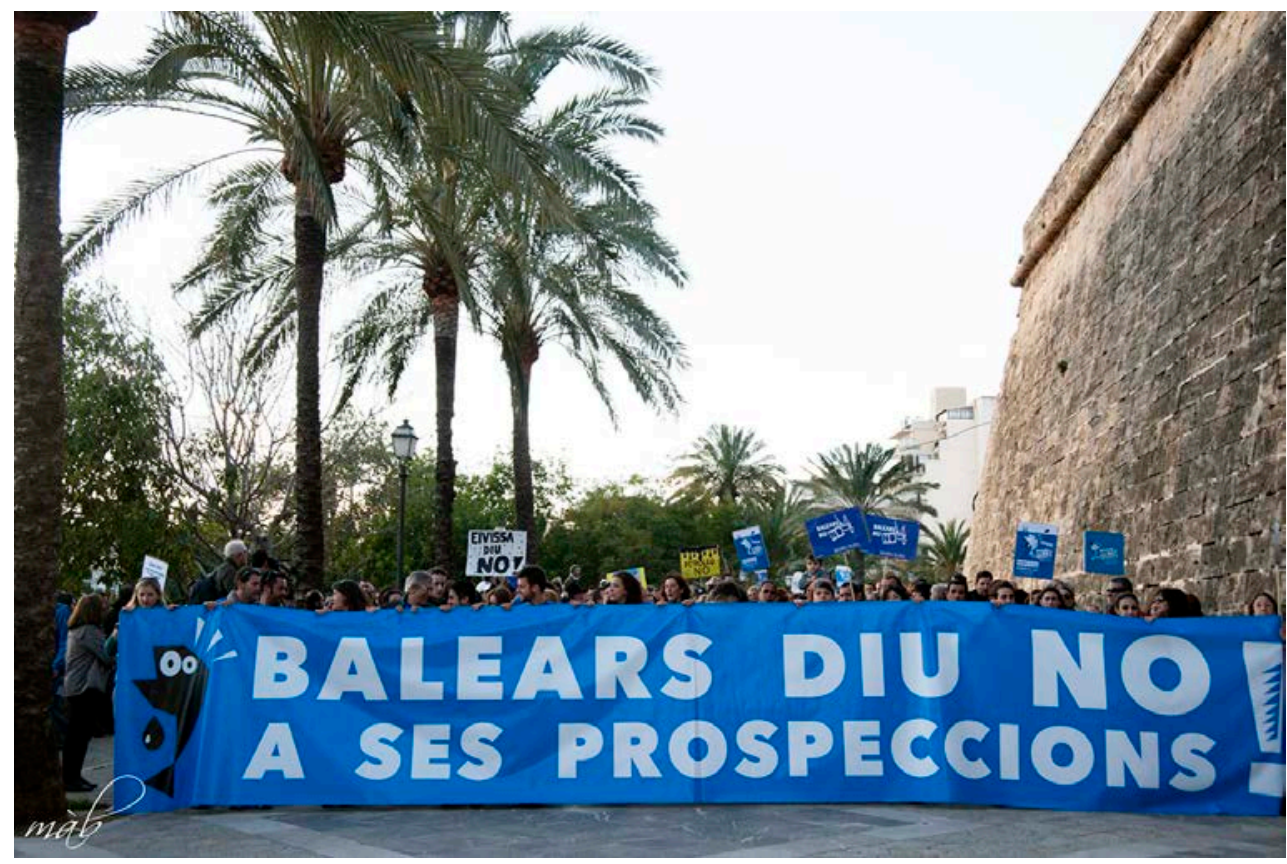

Figure 7: Demonstration against oil and gas prospecting (Palma, February 22, 2014). Source: Miquel Àngel Ballester.

This article is an attempt to do this, but further development is needed to connect flows of fish with flows of power, and especially fish-trade flows. Since fish imports are a key aspect of the social metabolism of fisheries in the Balearics, they should be analyzed more. I found that the fishing crisis in the Balearics is not simply a matter of fish stock depletion, but it is a complex historico-political process. Local fishing activities have been replaced by more profitable tourism, including recreational fishing. The constant reduction of fishing revenues explains the loss of the local industry, and is the main reason that an ageing population of fishers try to increase fish catches by other means. Artisanal small-scale fishing, and its culture, is being lost. A more radical transformation of fisheries at the Balearics would entail degrowth (D'Alisa et al. 2014) of the trawling fleet and further tourism investments (Hall 2009).

Finally, in the wake of the end of cheap oil and the "peak of everything" (Heinberg 2007), I argued capital is preparing for a global ocean grab as a means to appropriate resources and expand financial logics (Pedersen et al. 2014). Radical scholars and grass-root movements will have to address marine issues further in their research and political action.

\section{References}

Adriaanse, A., S. Brigenzu, A. Hammond, Y. Moriguchi, E. Rodenburg, D. Rogich and H. Schütz. 1997. Resource flows: the material basis of industrial economies. Washington DC: World Resource Institute.

Agnew, D., J. Pearce, G. Pramod, T. Peatman, R. Watson, J.R. Beddington and T.J. Pitcher. 2009. Estimating the worldwide extent of illegal fishing. Plos One 4 (2): 1-8.

Alenyà, M. 1984. Introducció a l'economia de les Balears. Palma: Edicions Cort.

Amer, J. 2006. Turisme i política. L'empresariat hoteler de Mallorca. Palma: Documenta Balear.

Ansola, A. 2008. ¡Arriba la pesca!: el discurso de la política social pesquera durante el Primer Franquismo. Áreas 27: 95-103. 
Artigues, A.A., A. Bauzà, M. Blázquez, J.M. González, O. Rullan, S. Vives and I. Yrigoy. 2013. La profundización de la vía urbano-turística-financiera en Palma (2007-2011). In Observatorio Metropolitano de Madrid (eds.) Paisajes devastados. Después del ciclo inmobiliario: impactos regionales y urbanos de la crisis. Madrid: Traficantes de Sueños. pp. 355-388.

Aspiroz, L. 2003. La economía balear en la era de Franco. La autarquía (1939-1949). Palma: La Lucerna.

Balata, F., S. Devlin, A. Esteban and R. Crilly. 2014. Fish dependence - 2014 update. The reliance of the EU on fish from elsewhere. London: New Economics Foundation, OCEAN2012 [Accessed February 24 2015].

Barkin, D., M.E. Fuente and D. Tagle. 2012. La significación de una Economía Ecológica radical. Revista Iberoamericana de Economía Ecológica 19: 01-14

Beizsley, D. 2015. Financialisation of infrastructure: the true cost. ODG [Accessed August 9 2015.]

Benjaminsen, T.A. and I. Bryceson. 2012. Conservation, green/blue grabbing and accumulation by dispossession in Tanzania. The Journal of Peasant Studies 39 (2): 335-355.

Bennett, N.J., H. Govan and T. Satterfield. 2015. Ocean grabbing. Marine Policy 57: 61-68.

Blázquez, M. 2013. More villas and more barriers: gentrification and the enclosure of rural land on Majorca. Méditerranée: revue geógraphique des pays méditerranéens 120: 25-36.

Blázquez, M., I. Murray and O. Rullan. 2010. El consumisme territorial i els gestos d'autocontenció a les Illes Balears. In J. Mayol, Ll. Muntaner and O. Rullan, O. (eds.) Homenatge a Bartomeu Barceló i Pons, geògraf. Palma: Lleonard Muntaner. pp. 371-390.

Blázquez, M., E. Cañada and I. Murray. 2011. Búnker playa-sol. Conflictos derivados de la construcción de enclaves de capital transnacional turístico español en El Caribe y Centroamérica. Scripta Nova 15 (368).

Bleischwitz, R., P.J.J. Welfens and Z. Zhang (eds.). 2011. International economics of resource efficiency ecoinnovation policies for a green economy. London: Physica-Verlag.

Borucke, M., D. Moore, G. Cranston, K. Gracey, K., Iha, J. Larson, E. Lazarus, J.C. Morales, M. Wackernagel and A. Galli. 2013. Accounting for demand and supply of the biosphere's regenerative capacity: the National Footprint Accounts' underlying methodology and framework. Ecological Indicators 24: 518-533.

Brich, K. and V. Mykhenko (eds.). 2010. The rise and fall of neoliberalism: the collapse of an economic order? London: Zed Books.

Brown, J., G. Macfadyen, T. Huntington, J. Magnus and J. Tumilty. 2005. Ghost fishing by lost fishing gear. Final Report to DG Fisheries and Maritime Affairs of the European Commission. Fish/2004/20. London: Institute for European Environmental Policy/Poseidon Aquatic Resource Management.

Bunker, S.G. 1996. Raw materials and the global economy: oversights and distortions in industrial ecology. Society and Natural Resources 9: 419-429.

Bunker, S.G. and P.S. Cincantell. 2005. Globalization and the race for resources. Baltimore: The John Hopkins University Press.

Burkett, P. 2010. Marxism and ecological economics. Chicago: Haymarket Books.

Caddy, J.F. and R.C. Griffiths. 1991. Tendencias recientes en las pesquerias y el medio ambiente en la zona del Consejo General de Pesca del Mediterráneo. Rome: FAO.

CAMAT. 2010. Estadístiques bàsiques de l'agricultura, la ramaderia i la pesca a les Illes Balears 2009. Conselleria d'Agricultura, Medi Ambient i Territori, Govern de les Illes Balears, Palma.

Campling, L., E. Havice and P McCall Howards. 2012. The political economy and ecology of capture fisheries: market dynamics, resource access and relations of exploitation and resistance. Journal of Agrarian Change 12 (2-3): 177-203.

Carpintero, O. 2005. El metabolismo de la economía española. Recursos naturales y huella ecológica (19552000). Lanzarote: Fundación César Manrique.

Carpintero, O. 2013. When heterodoxy becomes orthodoxy: ecological economics in The New Palgrave Dictionary of Economics. American Journal of Economics and Sociology 72 (5): 1287-1314. 
Carpintero, O. (dir.). 2015. El metabolismo económico regional español, Madrid: FUHEM Ecosocial.

Carreras, M., M. Coll, A. Quetglas, R. Goñi, X. Pastor, M.J. Cornax, M. Iglesia, E. Massutí, P. Oliver, R. Aguilar, A. Au, K. Zylich and D. Pauly. 2015. Estimates of total fisheries removal for the Balearic Islands (1950-2010). Fisheries Centre Research Report Working Paper 19.

Clausen, R. and B. Clark. 2005. The metabolic rift and marine ecology: an analysis of the ocean crisis within capitalist production. Organization and Environment 18 (4): 422-444.

Coll, M., M. Carreras, M.J. Cornax, E. Massutí, E. Morote, , X. Pastor, T. Quetglas, R. Sáez, L. Silva, I. Sobrino, M.A. Torres, S. Tudela, S. Harper, D. Zeller and D. Pauly. 2014. Closer to reality: reconstructing total removals in mixed fisheries from southern Europe. Fisheries Research 154: 179194.

Coll, M., I. Palomera, S. Tudela and F. Sardà. 2006. Trophic flows, ecosystem structure and fishing impacts in the south Catalan Sea, Northwestern Mediterranean. Journal of Marine Systems 59 (1-2): 63-96.

Coll, M., I. Palomera, S. Tudela and M. Dow. 2008. Food-web dynamics in the South Catalan Sea ecosystem (NW Mediterranean) for 1978-2003. Ecological Modelling 217, pp. 95-116.

Coll, M., C. Piroddi, C. Albouy, F.B.R. Lasram, W.W.L. Cheung, V. Christensen, V. Karpouzi, F. Guilhaumon, D. Mouillot, M. Paleczny, M.L. Palomares, J. Steenbek, P. Trujillo, R. Watson and D. Pauly. 2011. The Mediterranean sea under siege: spatial overlap between marine biodiversity, cumulative threats and marine reserves. Global Ecology and Biogeography 21 (4): 465-480.

Compán, D., 1975-1976. La pesca marítima en España. Cuadernos Geográficos 5-6: 87-176.

Conselleria de Medi Ambient. 2004. Balance de vertidos de gases de efecto invernadero a la atmósfera en el conjunto de las Islas Baleares en el año 2001. Palma: Govern de les Illes Balears.

Cousins, J.J. y Newell, J.J. 2015. A political-industrial ecology of water supply infrastructure. Geoforum 58: 38-50.

D'Alisa, G., F. Demaria and G. Kallis (eds.). 2014. Degrowth: a vocabulary for a new era. London: Routledge.

de Leo, F., P.P. Miglietta and S. Pavlinović. 2014. Marine ecological footprint of Italian Mediterranean fisheries. Sustainability 6: 7482-7495.

Delgado-Ramos G.C. 2015. Water and the political ecology of urban metabolism: the case of Mexico City. Journal of Political Ecology 22: 98-114.

Dicken, P. 2015. Global shift. mapping the changing contours of the world economy. London: Sage (7th edition).

Ditton, R.B., S.M. Holland and D.K. Anderson. 2002. Recreational fishing as tourism. Fisheries 27 (3): 1724.

Dunford, M. 2014. Mediterranean economies: the dynamics of uneven development. In R. King, L. Proudfoot and B. Smith (eds.) The Mediterranean: environment and society. New York: Routledge. Pp. 126-154.

EC. 2012. Blue Growth opportunities for marine and maritime sustainable growth. COM (2012) 494 final. Brussels: European Commission

Erb, K.H., F. Krasumann, W. Lucht and H. Haberl. 2009. Embodied HANPP: mapping the spatial disconnect between global biomass production and consumption. Ecological Economics 69 (2):. 328-334.

Etxezarreta, M. (coord.) 1991. La reestructuración del capitalismo en España 1970-1990. Barcelona: Icaria.

EUROSTAT, 2012. Economy-wide material flow accounts (EW-MFA). Compilation Guide 2012. Luxembourg: European Commission.

FAO. 1989. Yield and nutritional value of the commercially more important fish species. FAO Fisheries Technical Paper 309, Rome.

Fairhead, J., M.Leach and I. Scoones. 2012. Green Grabbing: a new appropriation of nature? The Journal of Peasant Studies 39 (2): 237-261.

Fernández-Durán, R. 2005. La compleja construcción de la Europa superpotencia. Barcelona: Virus.

Fischer-Kowalski, M. and H. Haberl (eds.). 2007. Socioecological transitions and global change: trajectories of social metabolism and land use. Cheltenham: Edward Elgar. 
Fischer-Kowalski, M., F. Krausmann, S. Giljum, S. Lutter, A. Mayer, S. Bringezu, Y. Moriguchi, H. Schütz, H. Schandl and H. Weisz. 2011. Methodology and indicators of economy-wide material flow accounting. Journal of Industrial Ecology 15 (6): 855-875.

Folke, C., N. Kautsky, H. Berg, A. Jansson and M. Troell. 1998. The ecological footprint concept for sustainable seafood production: a review. Ecological Applications 8 (1): 563-571.

Font, T. and J. Lloret. 2014. Biological and ecological impacts ferived from recreational fishing in Mediterranean coastal areas. Reviews in Fisheries Science and Aquaculture 22: 73-85.

Forment, A. 2000. José Martínez: la epopeya de Ruedo Ibérico. Barcelona: Anagrama.

Foster, J.B. 2000. Marx's ecology. Materialism and nature. New York: Monthly Review Press.

Foster, J.B., B. Clark and R. York. 2010. The ecological rift: capitalism's war on the earth. New York: Monthly Review Press.

Froese, R. and D. Pauly (eds.), 2014. FishBase. www.fishbase.org. version (06/2014) [accessed January 2 2014].

Garau, J.B., 2006. El turismo de cruceros en las Illes Balears. Palma: INESTUR-CAEB.

Giampietro, M. and A. Saltelli. 2014. Footprints to nowhere. Ecological Indicators 46: 610-621.

Goffredo, S. and Z. Duinsky (eds.). 2013. The Mediterranean Sea: its history and present challenges. London: Springer.

Grau, A.M., 2008. Recreational maritime fishing in the Balearic Islands: tradition and future. In B. Basurco, (ed.) The Mediterranean fisheries sector: a reference publication for the VII meeting of Ministers of agriculture and fisheries of CIHEAM member countries. Zaragoza: CIHEAM/FAO/GFCM (Options Méditerranéennes: Série B. Etudes et Recherches; n. 62). Pp. 97-105.

Guijarro B, F. Ordines and E. Massuti. 2010. Stock assessment on Merluccius merluccius in Balearic Islands (GSA 05). SAC GFCM Sub Committee on Stock Assessment.

Guijarro, B. 2012. Population dynamics and assessment of exploited deep water decapods of Balearic Islands (Western Mediterranean): from single to multi-species approach. PhD Thesis. Palma: Universitat de les Illes Balears.

Hall, M. 2009. Degrowing tourism: décroissance, sustainable consumption and steady-state tourism. Anatolia 20 (1): 46-61.

Halpern, B.S., S.Walbridge, K. Selkoe, , C.V. Kappel, F. Micheli, C. D'Agrosa, J.F. Bruno, K.S. Casey, C. Ebert, H.E. Fox, R. Fujita, D. Heinemann, H.S. Lenihan, E.M.P. Madin, , M.T. Perry, E.R. Selig, M. Spalding, R. Steneck and R. Watson. 2008. A global map of human impact on marine ecosystems. Science 319: 948-952.

Healy, H., J. Martínez-Alier, L. Temper, M. Walter and J.F. Gerber. 2013. Ecological economics from the ground up. London: Routledge.

Heinberg, R., 2007. Peak everything: waking up to the century of declines. Gabriola Island: Clairview Books.

Heynen, N., M. Kaika and E. Swyngedouw (eds.). 2006. In the nature of cities: urban political ecology and the politics of urban metabolism. London: Routledge.

Hoefle, W.S. 2014. Fishing livelihoods, seashore tourism, and industrial development in Coastal Rio de Janeiro: conflict, multi-functionality, and juxtaposition. Geographical Research 52 (2): 198-211.

Hof, A. and M. Blázquez. 2015. Changing tourism patterns, capital accumulation, and urban water consumption in Mallorca, Spain: a sustainability fix? Journal of Sustainable Tourism 23 (5): 770-796.

Hornborg, A. 2007. Footprints in the cotton fields: the industrial revolution as time-space appropriation and environmental load displacement. In A. Hornborg, J.R. McNeill and J. Martinez-Alier (eds.) Rethinking environmental history: world-system history and global environmental change. Lanham: AltaMira Press. Pp. 259-272.

Hornborg, A. 2012. Global ecology and unequal exchange. New York: Routledge.

Hornborg, A., J.R. McNeill, and J. Martinez-Alier (eds.). 2007. Rethinking environmental history: worldsystem history and global environmental change. Lanham: Altamira Press. 
Hosteltur. 2014. Movimiento empresarial contra las prospecciones de petróleo en Baleares. [Accessed August 10 2015]

INE. 2012. EPA. Encuesta de población activa. (www.ine.es) [Accessed December 21 2014].

Infante-Amate, J., D. Soto, E. Aguilera, R. García-Ruiz, G. Guzmán, A. Cid and M. González de Molina. 2015 in press. The Spanish transition to industrial metabolism: long-term material flow analysis (1860-2010). Journal of Industrial Ecology.

Kaplam, D.E. (eds.). 2012. Looting the seas. Washington DC: The Center for Public Integrity, The International Consortium of Investigative Journalists.

Kautsky, N., H. Berg, C. Folke, J. Larsson and M. Troell. 1997. Ecological footprint for assessment of resource use and development limitations in shrimp and tilapia aquaculture. Aquaculture Research 28 (10): 753-766.

Kelleher, K. 2005. Discards in the world's marine fisheries: an update. Rome: FAO Fisheries Technical Paper 470.

Kim, W.C. and R. Mauborgne. 2005. Blue Ocean Strategy: how to create uncontested market space and make the competition irrelevant. Boston: Harvard Business School Press.

Klare, M.T. 2012. The race for what's left: the global scramble for the world's last resource. New York: Metropolitan Books.

Lloret, J. and T. Font. 2013. A comparative analysis between recreational and artisanal fisheries in a Mediterranean coastal area. Fisheries Management and Ecology 20: 148-160.

Longo, S.B. 2011. Global Sushi: the political economy of the Mediterranean Bluefin Tuna fishery in the modern era. Journal of World-Systems Research 17 (2): 403-427.

Longo, S.B. 2012. Mediterranean rift: socio-ecological transformations in the Sicilian Bluefin Tuna fishery. Critical Sociology 38: 417-436.

Longo, S.B., R. Clausen and B. Clark. 2015. The tragedy of the commodity: oceans fisheries and aquaculture. New Brunswick: Rutgers University Press.

López, I. and E. Rodríguez. 2010. Fin de ciclo. Financiarización, territorio y sociedad de propietarios en la onda larga del capitalismo hispano (1959-2010). Madrid: Traficantes de Sueños.

Lovelock, B., K. Lovelock and Ø. Normann. 2010. The big catch: negotiating the transition from commercial fisher to tourism entrepreneur in island environments. Asia Pacific Journal of Tourism Research 15 (3): 267-283.

Lucas, A.M., 2002. Les activitats agràries, pesqueres i forestals a les Illes Balears. Palma: Govern de les Illes Balears,.

Magdoff, F. and B. Tokar (eds.). 2010. Agriculture and food in crisis: conflict, resistance, and renewal. New York: Monthly Review Press.

Manera, C. and A. Morey. 2006. La empresa en Baleares: flexibilidad y capacidad de adaptación al cambio económico 1850-2000. In J.L. García-Ruíz and Manera, C. (eds.) Historia empresarial de España. Un enfoque regional en profundidad. Madrid: LID Editorial. Pp. 79-112.

Mansfield, B. 2004. Neoliberalism in the oceans: "Rationalization", property rights, and the commons question. Geoforum 35 (3): 313-326.

Mansfield, B. 2011. "Modern" industrial fisheries and the crisis of overfishing. In R. Peet, P. Robbins and M.J. Watts (eds.) Global political ecology. London: Routledge. Pp. 84-99.

Mansfield, B. 2010. Is fish health food or poison? Farmed fish and the material production of un/healthy nature. Antipode 43 (2): 413-434.

Margalef, R. 1992. Planeta azul, planeta verde. Barcelona: Prensa científica.

Martín-Sosa, S. (coord.) 2015. Resistencia global al fracking. El despertar ciudadano ante la crisis climática y democrática. Madrid: Los Libros en Acción.

Martínez-Alier, J. 1987. Ecological economics. energy, environment and society. Oxford: Blackwell. 
Martínez-Alier, J. 2007. Marxism, social metabolism, and international trade. In A. Hornborg, J.R. McNeill and J. Martinez-Alier (eds.) Rethinking environmental history: world-system history and global environmental change. Lanham: AltaMira Press. Pp. 221-237.

Martínez-Alier, J. 2011. El ecologismo de los pobres. Conflictos ambientales y lenguajes de valoración. Barcelona: Icaria.

Marx, K. 1990. Capital. Volume I. London: Penguin Books.

Massutí, M. 1973. Evolución de los esfuerzos y rendimientos de pesca en la región Balear entre los años 1940 a 1970. Publicacion Técnica Dirección General Pesca Maritima 10: 37-54.

Massutí, M. 1989. El libro azul de la pesca balear. Palma: Govern Balear.

Massutí, M. 1994. Els recursos pesquers del mar balear. Bases per a una explotació sostenible. Palma:, Govern Balear.

Maynou, F., B. Morales-Nin, M. Cabanellas, M. Palmer, E. García and A. Grau. 2013. Small-scale fishery in the Balearic Islands (W Mediterranean): a socio-economic approach. Fisheries Research 139: 11-17.

Mayol, J., A. Grau, F. Riera and J. Oliver. 2000. Llista vermella dels peixos de les Balears. Palma: Govern de les Illes Balears.

M'Gonigle, R.M. 1999. Ecological economics and political ecology: towards a necessary synthesis. Ecological Economics 28 (1): 11-26.

Mora, J. 2015. Ens salven els pescadors de Senegal. Jaume Enseñat canta les veritats del sector pesquer solleric i reclama que les autoritats establesquin períodes de veda. Sa Veu de Sóller 26/06/2015:30.

Morales-Nin, B., F. Cardona, F. Maynou and A. Grau. 2015. How relevant are recreational fisheries? Motivation and activity of resident and tourist anglers in Majorca. Fisheries Research 164: 45-49.

Morales-Nin, B., A. Grau and M. Palmer. 2010. Managing coastal zone fisheries: a Mediterranean case study. Ocean and Coastal Management 53: 99-106.

Morales-Nin, B., J. Moranta, C. García, L. Cardona, D. López, M. Cerdà, A. Grau, F. Riera, T. Bosch and S. Martino. 2004. Seguiment de la pesca recreativa a les Illes Balears. Determinació de l'esforç i de les captures (Projecte IFOP ES/R/BAL 5.1.3). Palma: Govern de les Illes Balears.

Morales-Nin, B., J. Moranta, C. García, M.P. Tugores, A. Grau, F. Riera and M. Cerdà. 2005. The recreational fishery of Majorca Island (western Mediterranean): some implications for coastal resource management. ICES Journal of Marine Science 62 (4): 727-739.

Moranta J., E. Massutí and B. Morales-Nin. 2000. Fish catch composition of the deep-sea decapod crustacean fisheries in the Balearic islands (western Mediterranean). Fisheries Research 45 (3): 253-264.

Morell, M. and J. Franquesa. 2011. Playing snakes and ladders in Ciutat de Mallorca: an ethnographic approach to the production of the neighbourhood scale. In M. Kousis, A.T. Selwyin and D. Clark (eds.) Contested Mediterranean spaces: ethnographic essays in honour of Charles Tilly. New York: Berghahn Books. Pp. 231-261.

Mulazzani, L. and G. Malorgio. 2015. Is there coherence in the European Union's strategy to guarantee the supply of fish products from abroad? Marine Policy 52: 1-10.

Murray, I. 2012. Geografies del capitalisme balear. Poder, metabolisme socioeconòmic i petjada ecològica d'una superpotència turística. Ph.D. Thesis. Palma: Universitat de les Illes Balears.

Murray, I. 2013. Breu història d'un port de la Mediterrània. El Port de Sóller, de port mariner a port turísticoresidencial. [Accessed March 1 2014].

Murray, I. 2015. Capitalismo y turismo en España. Del "milagro económico" a la "gran crisis". Barcelona: Alba Sud Editorial.

Naredo, J.M., M. Gaviria and J. Serna (eds.). 1977. Extremadura saqueada: recursos naturales y autonomía regional. Barcelona: Ruedo Ibérico.

Naredo, J. M., 2010. Raíces económicas del deterioro ecológico y social. Más allá de los dogmas. Madrid: Siglo XXI.

Naredo, J.M. 2015. La economía en evolución. Historia y perspectivas de las categorías básicas del pensamiento económico. Madrid: Siglo XXI. 
Newell, J.P. and Cousins, J.J. 2014 in press. The boundaries of urban metabolism: towards a politicalindustrial ecology. Progress in Human Geography.

OCEANA 2011a. Pesca artesanal responsable: el futuro de la pesca en las Illes Balears. [Accessed January 19 2015].

OCEANA. 2011b. La Pesca de arrastre: una pesca en decadencia que necesita de una urgente racionalización. [Accessed January 19 2015].

OCEANA. 2012. Comentaris d'Oceana a l'esborrany de l'avantprojecte de Llei de pesca marítima, marisqueig i aqüicultura a les Illes Balears [Accessed January 19 2015].

Olaizola, I. 2015. Los pescadores niegan el volumen de capturas denunciado por Oceana. Diario de Mallorca [Accessed August 7 2015]

Oliver, P. 1993. Analysis of fluctuations observed in the trawl fleet landings of the Balearic Islands. Scientia Marina 57(2-3): 219-227.

Ordines, F., E. Massutí, B. Guijarro and R. Mas. 2006. Diamond vs. square mesh codend in a multi-species trawl fishery of the western Mediterranean: effects on catch composition, yield, size selectivity and discards. Aquatic Living Resources 19 (4): 329-338.

Pastor, X. (ed.). 2007. Illes Balears: propuesta para la gestión de hábitats amenazados y la pesca. OCEANA, Madrid.

Pauli, G. 2010. Blue economy-10 years, 100 innovations, 100 million jobs. New Mexico: Paradigm Publications.

Pauly, D. and M.L. Palomares. 2005. Fishing down marine food web: it is far more pervasive than we thought. Bulletin of Marine Science 76 (2): 197-211.

Pauly, D. and V. Christensen. 1995. Primary production to sustain global fisheries. Nature 374: 255-257.

Pauly, D., V. Christensen, S. Guénette, T.J. Pitcher, U.R. Sumaila, C.J. Walters, R. Watson and D. Zeller. 2002. Towards sustainability in world fisheries. Nature 418: 689-695.

Pauly, D., A. Ulman, C. Piroddi, E. Bultel and M. Coll. 2014. 'Reported' versus 'likely' fisheries catches of four Mediterranean countries. Scientia Marina 78 (1): 11-17.

Pedersen, C., T. Feodoroff, R. Reuter, J. Franco, N. Buxton and M.C. Barbesgaard. 2014. The global ocean grab. Amsterdam: Transnational Institute.

Peet, R., P. Robbins and M.J. Watts (eds.). 2010. Global political ecology. London: Routledge.

Pereira, J.A., 2002. Recursos marinos. Recursos pesqueros en el marco de la Unión Europea. In J.M. Naredo and F. Parra (eds.) La situación diferencial de los recursos naturales Españoles. Lanzarote: Fundación César Manrique. Pp. 299-317.

Planeles, M. 2015. La petrolera escocesa Cairn Energy cierra sus oficinas en España. El País [Accessed 10 August 2015]

Pons, A., O. Rullan and I. Murray. 2014. Tourism capitalism and island urbanization: tourist accommodation diffusion in the Balearics, 1936-2010. Island Studies Journal 9 (2): 239-258.

Pons, A. and O. Rullan. 2014. Artificialization and islandness on the Spanish tourist coast. Miscellanea Geographica 18 (1): 5-16.

Pujol, X. 2001. Indicios de yacimientos de petróleo rentables en el Mediterráneo occidental. El País [Accessed 10 August 2015]

Quetglas, A., B. Guijarro, F. Ordines and E. Massutí. 2012. Stock boundaries for fisheries assessment and management in the Mediterranean: the Balearic Islands as a case study. Scientia Marina 76(1): 17-28

Quetglas, A., F. Ordines, M. Hidalgo, S. Monserrat, S. Ruiz, A. Amores, J. Moranta and E. Massuti. 2013. Synchronous combined effects of fishing and climate within a demersal community. ICES Journal of Marine Science 70 (2): 319-328.

Rayó, M. 2004. L'ecologisme a les Balears. Palma: Documenta Balear.

Rodríguez, E. 2015. Por qué fracasó la democracia en España. La transición y el régimen del 78. Madrid: Traficantes de Sueños. 
Saguin, K., 2014. Biographies of fish for the city: urban metabolism of Laguna Lake aquaculture. Geoforum 54: 28-38.

Sastre, S., O. Carpintero, P. Lomas. 2015. Regional Material Flow Accounting and environmental pressures: the Spanish case. Environmental Science and Technology 49(4): 2262-2269.

Secretaría de Estado de Comercio. 2015. Datacomex. Estadística del comercio exterior español. [Accessed January 12 2014].

Sinde, A.I. 2008. Expansión y modernización de la flota pesquera española tras la Guerra Civil: estado, empresa y construcción naval. Áreas 27: 58-67.

Smith, N. 2010. Uneven development: nature, capital and the production of space. London: Verso.

Spash, C.L. 2011. Social ecological economics: understanding the past to see the future. American Journal of Economics and Sociology 70 (2): 340-375.

Stambler, N. 2014. The Mediterranean sea - pimary productivity. In Goffredo, S. and Z. Dubinsky (eds.) The Mediterranean Sea: its history and present challenges. London: Springer. Pp. 113-121.

Suárez, J.L. and I. Martínez. 2012. La política marítima y la planificación espacial. aplicación metodológica al arco Atlántico-Mediterráneo. Propuestas de regionalización de las aguas jurisdiccionales españolas. Sevilla: Universidad de Sevilla.

Swartz, W., E. Sala, S. Tracey, R. Watson and D. Pauly. 2010. The spatial expansion and ecological footprint of fisheries (1950 to Present). PLoS One 5 (12): 1-6.

Swyngedouw, E. (2006). Metabolic urbanization: the making of cyborg cities. In N. Heynen, M. Kaika and E. Swyngedouw (eds.) In the nature of cities. urban political ecology and the politics of urban metabolism. London: Routledge. Pp. 21-40.

Talberth, J., J. Venetoulis and K. Wolowicz. 2007. Recasting marine ecological fishprint accounts. Oakland: Redefining Progress.

The Economist. 2015. Investing in the blue economy: growth and opportunity in a sustainable ocean economy. Economist Insights report. [Accessed 9 August 2015.]

Tsagarakis, K., V. Vassilopulou, A. Kallianiotis and A. Machias. 2012. Discards of the purse seine fishery targeting small pelagic fish in the eastern Mediterranean Sea. Scientia Maritima 76 (3): 561-572.

Tyedmers, P. 2004. Fisheries and energy use. In Cleveland, C. (ed.) Encyclopedia of energy. Amsterdam: Elsevier Science. Pp. 683-693.

Tyedmers, P., R. Watson and D. Pauly. 2005. Fueling global fishing fleets. Ambio 34 (8): 635-638.

Tzanatos, E. and S. Somarakis. 2007. Discarding practices in a Mediterranean small-scale fishing fleet (Patraikos Gulf, Greece). Fisheries Management and Ecology 14 (4): 277-285.

Velasco, T. 1992. La flota pesquera de las islas Baleares. Revista de Geografía 26: 67-86.

Vives, S. 2011. Producing a successful city: neoliberal urbanism and gentrification in the tourist city: the case of Palma (Majorca). Urban Studies Research 2011: 1-13.

Wackernagel, M. and W. Rees. 1996. Our ecological footprint. Reducing human impact on earth. Gabriola Island: New Society Publishers.

Walker, P.A. 2005. Political ecology: where is the ecology? Progress in Human Geography 29 (1): 73-82.

Watson, R., D. Zeller and D. Pauly. 2014. Primary productivity demands of global fishing fleets. Fish and Fisheries 15 (2): 231-241.

Zeller, D., Pauly, D., 2005. Good news, bad news: global fisheries discards are declining, but so are total catches. Fish and Fisheries 6 (2): 156-159.

Ziegler, F., U. Winther, E.S. Hognes, A. Emanuelsson, V. Sund and H. Ellingsen. 2012. The carbon footprint of Norwegian products on the global seafood market. Journal of Industrial Ecology 17 (19): 103-116. 